\title{
Sylvatic cycles of arboviruses in non-human primates
}

\author{
Matthew John Valentine ${ }^{1 *+} \mathbb{B}$, Courtney Cuin Murdock ${ }^{2,3,4,5}$ and Patrick John Kelly ${ }^{6+}$
}

\begin{abstract}
Arboviruses infecting people primarily exist in urban transmission cycles involving urban mosquitoes in densely populated tropical regions. For dengue, chikungunya, Zika and yellow fever viruses, sylvatic (forest) transmission cycles also exist in some regions and involve non-human primates and forest-dwelling mosquitoes. Here we review the investigation methods and available data on sylvatic cycles involving non-human primates and dengue, chikungunya, Zika and yellow fever viruses in Africa, dengue viruses in Asia and yellow fever virus in the Americas. We also present current putative data that Mayaro, o'nyong'nyong, Oropouche, Spondweni and Lumbo viruses exist in sylvatic cycles.
\end{abstract}

Keywords: Sylvatic, Primates, Enzootic, Arboviruses, Mosquitoes, Chikungunya, Dengue, Zika, Yellow fever

\section{Background}

Many medically important and emergent arboviruses (arthropod-borne viruses) originated in non-human primates (NHPs), which typically show no clinical signs of infection but become viraemic and help maintain the virus in nature [1]. In the natural forest habitats of the NHPs, arboreal mosquitoes transmit arboviruses from infected to naïve animals in what is termed a sylvatic transmission cycle (NHP-mosquito-NHP-mosquito, etc.). People can become infected if they encroach on forest habitat (either through deforestation, hunting, agriculture, or urbanization) and are fed upon by mosquitoes carrying arboviruses, or if infected forest mosquitoes move into areas of human habitation to obtain a blood meal. When humans infected in the forest enter urban environments, arbovirus infections can rapidly spread amongst people transmitted by highly anthrophilic, urban mosquitoes. The sylvatic transmission cycle is then said to have 'spilled over' into an urban transmission cycle [2-5]. This is well documented in the case of the yellow fever virus (YFV), where amplifications in infected

\footnotetext{
*Correspondence: mvalentine@students.rossu.edu

${ }^{\dagger}$ Matthew John Valentine and Patrick John Kelly contributed equally to this work

${ }^{1}$ One Health Centre for Zoonoses and Tropical Veterinary Medicine, Ross University School of Veterinary Medicine, Island Main Road, West Farm, Basseterre, Saint Kitts and Nevis

Full list of author information is available at the end of the article
}

NHPs precede and lead to short-lived outbreaks in people $[3,6]$.

Urban transmission cycles of arboviruses in densely populated tropical regions can result in explosive epidemics and pandemics, although there can also be low levels of transmission only sufficient to maintain the viruses in the population. Some arboviruses, like dengue (DENV), chikungunya (CHIKV) and Zika (ZIKV), have become fully adapted to urban cycles and no longer require NHPs, forest mosquitoes and a sylvatic cycle for their maintenance [7]. However, sylvatic cycles could still have important implications for human infections. They may act as refugia for arboviruses which enable re-emergence once human epidemics have passed and immunity in the population (herd immunity) has waned. Further, they might provide selective environments where new strains of arboviruses can develop with increased (or decreased) virulence for people. Also, such novel strains may overcome immunity developed in response to vaccines designed for existing urban strains, so called 'vaccine redundancy' [8].

Because of the potential significance of sylvatic cycles, leading researchers [3, 9-11] have emphasised the importance of future investigations into their roles in the epidemiology of devastating diseases like dengue, chikungunya, yellow fever and Zika. Below we review the methods used to investigate sylvatic cycles and available epidemiological data on sylvatic cycles of arboviruses in 
NHPs, primarily focusing on the most recent and largest arbovirus outbreaks in people (Fig. 1).

\section{Investigation of sylvatic cycles}

For the purposes of this review, we regard a sylvatic cycle to be present if there is evidence of biological transmission (i.e. viral isolation, serological testing, blood-meal analysis and experimental infection) of an arbovirus between a NHP (the vertebrate host) and mosquitoes (vectors) that feed on them in a forest ecosystem (Table 1) $[3,7,10-15]$.

\section{Determining the infection status of the NHP}

As stated by Kuno \& Chang [15], "The three commonly used data for identifying vertebrate reservoirs for arboviruses have been (i) virus isolation from suspected animals, (ii) relatively high antibody prevalence in the animals captured in the field and (iii) demonstration of viraemia (of higher virus titre and duration) in the

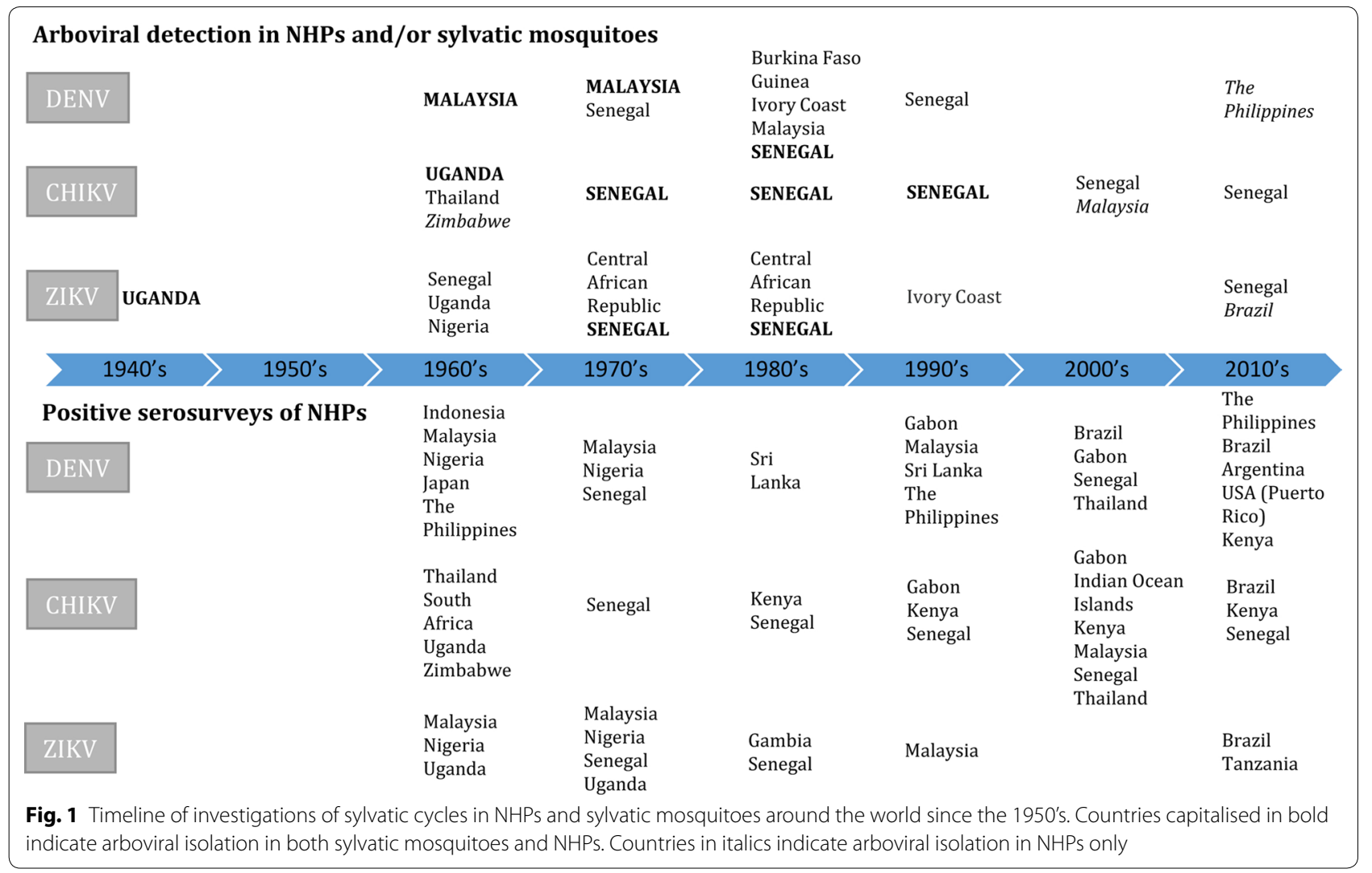

Table 1 Criteria and techniques used to establish the presence of arboviral sylvatic cycles

\begin{tabular}{ll}
\hline Criteria & Techniques employed to demonstrate the criteria \\
\hline $\begin{array}{l}\text { Sufficient populations of immuno-naïve (susceptible) NHPs } \\
\text { Sufficient viraemia in the NHP to infect feeding mosquitoes }\end{array}$ & Antibody detection \\
& Viral isolation from blood \\
& Viral genome detection from blood \\
$\begin{array}{l}\text { Sufficient populations of spatially and temporally coincident competent (capable of } \\
\text { viral transmission) infected mosquitoes that feed on NHPs }\end{array}$ & Mosquito capture and identification \\
& Virus detection in mosquitoes \\
& Blood-meal analysis of fed mosquitoes \\
& Observations of NHPs being fed upon by forest mosquitoes \\
& Viral transmission experiments (between NHPs and mosquitoes)
\end{tabular}


suspected animals typically obtained under laboratory conditions" [15].

\section{Viral isolation from suspected animals}

Isolation of virus from forest NHPs is strong evidence for a sylvatic cycle, however arboviral viremias are only short lived, from one to seven days [16-19]. Thus, finding virus, or identifying fragments of its genome in the case of PCR, in naturally infected animals during field studies is serendipitous [20-24].

\section{Relatively high antibody prevalence in the animals captured in the field}

Although antibody detection has been used to implicate NHPs in sylvatic cycles in more recent studies [10, 25, 26], stand-alone serology of NHPs, particularly by ELISA, is weak evidence of sylvatic transmission because antibodies only indicate previous exposure (potentially years) of the NHP to the virus and make no assessment of viral kinetics or transmission.

\section{Demonstration of viraemia (of higher virus titre and duration) in the suspected animals typically obtained under laboratory conditions}

The final evidence for a sylvatic cycle involves the experimental demonstration of a viraemia of sufficient titre to enable mosquitoes to become infected with subsequent transmission to other NHPs $[14,15]$. These data are typically obtained under laboratory conditions.

\section{Determining the infection status of forest-dwelling mosquitoes}

There are many different methods that can be used to investigate the mosquito-related criteria for establishing the presence of sylvatic cycles (Table 1). Various sampling techniques have been described to catalogue adult species of mosquito potentially involved in sylvatic cycles in the field [27]. These are based mainly on the target mosquito species and availability of resources and most commonly include, singly or in combination, human landing collections [28], specially designed traps [28, 29], handheld sweep nets, animal-baited net traps [30] and aspirators [31].

Diallo et al. [28] stated that human landing catches are "the only effective method for sampling sylvatic Aedes"; however, humans must be vaccinated against YFV and using malaria prophylaxis. Further, some would consider this technique unethical. There are a variety of mosquito traps that use attractants such as light, carbon dioxide, lures (specially designed scents) or animal bait, but often their use is hindered by limited resources in remote locations. Additionally, traps may require a power source to operate a fan and must be set and checked daily to prevent captured mosquitoes from desiccation which renders them unidentifiable. Animal-baited mosquito net traps are cheap and easy to use but mosquitoes readily escape and the enclosure can alter mosquito behaviour [27]. Handheld sweep nets and aspirators are labour intensive and not species-specific but aspiration is more successful at capturing blood-fed individuals [27]. Hosts on which mosquitoes feed can be discovered by direct observation [23] or by genotyping the blood meal found in engorged mosquitoes, so called blood meal analysis [32, 33].

Demonstration of virus in remote forest-dwelling mosquitoes that cohabit with and feed upon NHPs is considered reliable evidence for a sylvatic cycle [28-30], especially when combined with concurrent serological surveys or viral detection in NHPs. Viral presence can be determined by inoculation of cell cultures with homogenised monospecific pools of 30-50 mosquitoes and identification of virus in the supernatant by IFA, CFT, neutralisation tests or PCR on extracted RNA [28-30].

Confirming the above criteria (Table 1) and establishing with certainty that sylvatic cycles are present is often difficult in practice. Some studies, principally the early ones, established the existence of sylvatic cycles using the above criteria $[20-24,29,30]$. Other studies have relied more on investigating viral presence in either sylvatic mosquitoes [28] or NHPs [10].

\section{Laboratory tests used to investigate sylvatic cycles}

Laboratory methods used to detect arboviral infections in NHPs are virus isolation, nucleic acid amplification by PCR, and serological techniques [34, 35], while detection of infections in mosquitoes depend on virus isolation and/or PCR. As NHPs are only viraemic for relatively short periods after infection, serological testing is frequently used for demonstrating infections that generally result in the production of long-lasting antibody responses $[16,18,19,34]$.

\section{Arboviral detection in NHPs and mosquitoes}

Virus isolation is the gold standard for identifying infections in NHPs and mosquitoes and has the added advantage of providing viral isolates that can be fully investigated and characterised. It can be performed in vivo, originally by inoculation of infant mice, or in vitro by cultivation in mosquito cell lines (C6/36 Aedes albopictus or AP61 Aedes pseudoscutellaris) or mammalian cell lines (e.g. Vero). Virus isolation can be technically challenging, expensive and time consuming and is now only performed in laboratories with appropriate safety facilities [34].

Polymerase chain reaction testing is rapid, sensitive and specific and has now largely replaced viral isolation 
[34]. However, the sensitivity of the test means it can be prone to false negatives and the specificity depends on the primer design.

\section{Antibody detection in NHPs}

Arboviruses are a diverse group of nearly 500 viruses that are distributed across nine different viral families that share common morphological and molecular characteristics [35, 36]. With regard to sylvatic cycles in NHPs, the DENV, YFV, ZIKV and Spondweni (SPONV) are flaviviruses belonging to the family Flaviviridae while CHIKV, Mayaro (MAYV) and o'nyong'nyong (ONNV) are alphaviruses within the Togaviridae (Fig. 2). All are single-strand +ve-sense RNA viruses with the members of each family having close antigenic relationships to one another. Unfortunately, these antigenic similarities within the taxa can induce cross-reactive antibody responses causing uncertainty with serological diagnostic tests [34, 35]. Additionally, the concept of original antigenic sin arises when sequential infections by different arboviruses leads to a greater antibody response to the virus responsible for the first infection. This is a particular problem with the multiple serotypes of DENV. Additionally, DENV and ZIKV (Flaviviridae) possess similar antigenic surface epitopes (Flavivirus E protein) therefore eliciting indistinguishable antibody responses and false positives by some serological techniques [37, 38]. Alphaviruses have similar problems where, for example, methods targeting CHIKV antibodies to the E2EP3 protein (antiE2EP3) cross-react with non-CHIKV alphaviruses [39] like MAYV or ONNV. Fortuitously, anti-E2EP3 can be used to differentiate between CHIKV infections and Flavivirus infections with $93 \%$ accuracy [39]. It should be noted that some larger serological studies report results in terms of viral genera, i.e. Alphavirus- or Flaviviruspositive, thus not distinguishing the species.

\section{Haemagglutination inhibition (HAI)}

The HAI test is based on the fact that many viruses agglutinate erythrocytes in vitro. Antibodies present in test sera prevent this haemagglutination. Although HAI antibodies are long-lasting and the test is of high sensitivity, it lacks specificity $[40,41]$. However, it remains useful as a rapid screening test for viruses with common antigenic groups in epidemiological studies [34].

\section{Complement fixation test (CFT)}

Test sera is added to self-antibody coated sheep erythrocytes with a known concentration of exogenous complement proteins and the antigen of interest. If antibody

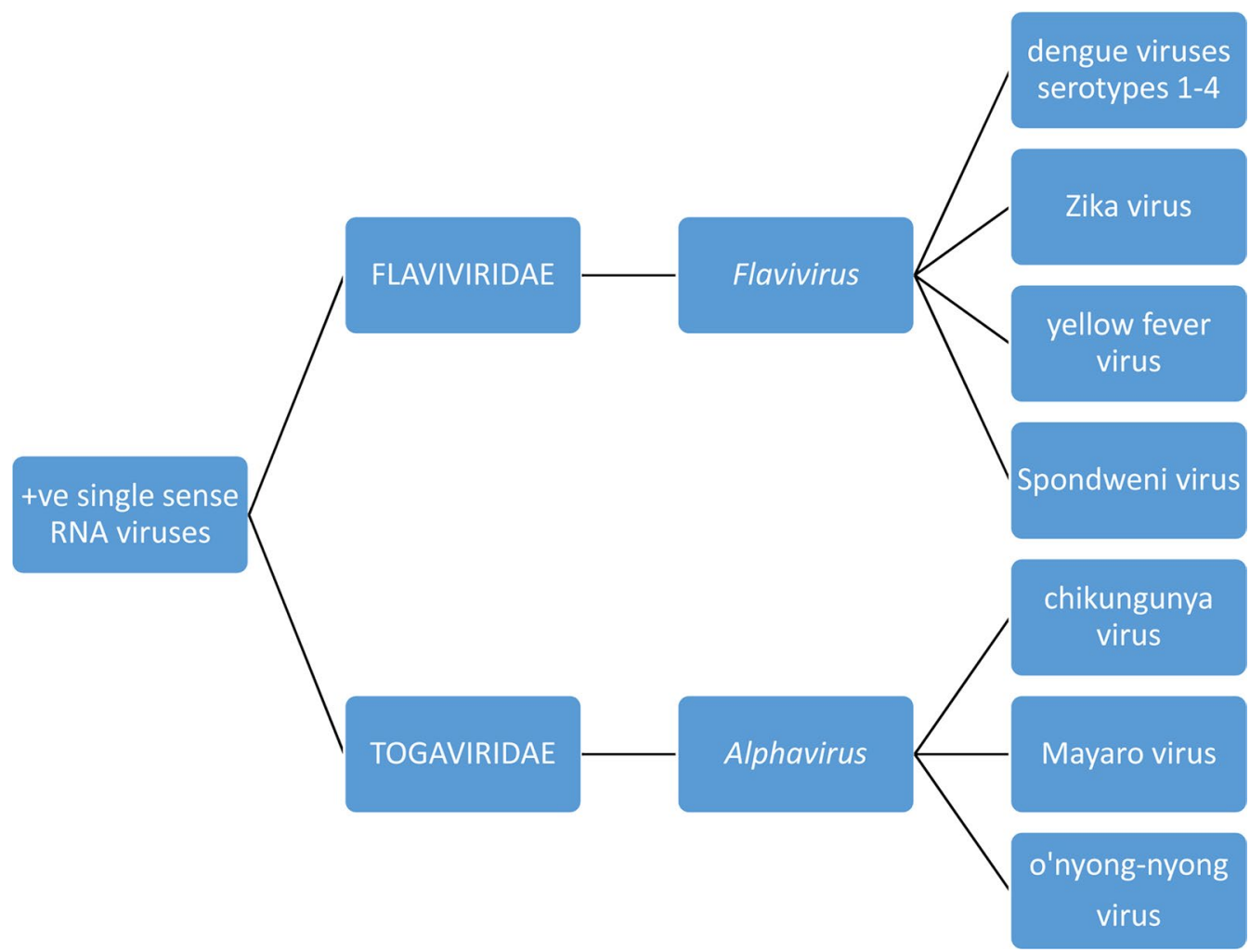

Fig. 2 Relationship and classification of arboviruses with known and putative sylvatic cycles involving NHPs 
is present in the test sera, antigen-antibody complexes will form and bind complement preventing erythrocyte lysis. The test is rarely used nowadays for diagnosis as it requires a high level of technical ability and has limited specificity as a stand-alone test [34].

\section{Enzyme-linked immunosorbent assay (ELISA)}

Many commercial human ELISA kits detecting immunoglobulin G (IgG) [and immunoglobulin M (IgM)] against the various arboviruses are available and have frequently been used for screening NHPs, particularly in dengue vaccine studies. Following a primary infection, IgM appear after 6-14 days and remain elevated for 60-90 days; their presence thus indicates recent exposure [42]. On the other hand, IgG are long-lasting and their presence can be evidence of infections many years previously [43]. In general, the commercial ELISAs are relatively simple, can be performed quickly and can be used for NHPs as the conjugated anti-human sera used in the kits also identify non-human primate antibodies. Although they have high sensitivity and are regarded as reliable screening tools, false positive results are possible due to serological cross-reactivity that occurs between similar arboviruses [34].

\section{Indirect immunofluorescence assay (IFA)}

Antigen is applied to a microscope slide and test sera overlaid. Reactive antibodies are detected with secondary fluorescent-labelled antisera and fluorescence microscopy. The test is highly sensitive but cross-reactions between viral genera and species reduce the specificity [34].

\section{Plaque reduction neutralisation test (PRNT)}

This is the gold standard test to demonstrate the presence of specific neutralising antibodies to the various arboviruses. Test sera containing neutralising antibody are added to virus infected cell culture monolayers to inhibit viral plaque formation. Positive results are reported as the dilution that produces a $50 \%$ or more reduction in plaque formation. The PRNT is quantitative and specific but unfortunately is time consuming, labourintensive, and requires a source of live virus and cell culture with appropriate laboratory containment facilities [34].

\section{Older neutralisation techniques}

In the past, the ability of antibodies in test sera to protect mice against viral challenge has been used to determine seropositivity $[44,45]$. As this test requires live animals, it is expensive and contravenes the ' 3 Rs' (replace, reduce and refine) guiding principles of the use of animals in scientific research [46].

\section{Blood-meal analysis by PCR of fed mosquitoes}

To determine the host ranges of mosquitoes, DNA can be extracted from the blood meals ingested by engorged females and tested by PCR for vertebrate host speciesspecific genes, for example the hydroxymethylbilane synthase (HMBS) gene. Sequencing of the PCR amplicons reveals the vertebrate sources of the blood meal with species that have genomic data available [32, 33].

\section{Natural dengue virus infections in NHPs and mosquitoes}

Dengue virus infections are responsible for more deaths and illness than any other arboviral infection in people across tropical and subtropical regions of the world, particularly in Asia and cases have recently increased in Africa [47]. Typical symptoms of infection include fever, myalgia, arthralgia and rashes (dengue fever) or more rarely, a life-threatening haemorrhagic diathesis and circulatory failure (severe dengue or dengue haemorrhagic fever). Dengue virus is a Flavivirus (Fig. 2) and exists in four ecologically distinct serotypes.

\section{Dengue virus infections in NHPs and sylvatic mosquitoes in Asia}

Following the elucidation of the 'jungle cycle' of yellow fever virus in the early 20th century, the possibility of DENV occurring in a sylvatic cycle in Southeast Asia was mooted by Simmons et al. [48]. During extensive experimental investigations in the 1930's in the Philippines, they found that NHPs from dengue-free areas could be infected with DENV and mosquitoes that fed on them could subsequently transmit the virus. In contrast, NHPs from dengue-endemic areas were resistant to DENV challenge because they had already been exposed to the virus and developed immunity.

More than 20 years later, Smith [49] postulated that arboreal animals on the Malaysian peninsula were a reservoir for DENV and that infections were maintained by mosquitoes that do not feed at ground level. Hammon et al. [50] reported neutralising antibodies in urban monkeys in Bangkok, but they did not test for reactivity with arboviruses closely related to DENV and, although the specificity of the results were questioned, the possibility of 'jungle dengue' in Malaysia was not excluded [51].

Conclusive proof of a sylvatic cycle of DENV involving NHPs in the forests of Malaysia was provided by an extensive study between 1962 and 1980 involving domestic animals (cats, chickens, cattle, dogs, ducks, geese, horse and pigs), over 8000 wild vertebrates (mudskippers, 
Table 2 Chronological arrangement of reports of laboratory confirmed natural infections of NHPs with DENVs in countries around the world

\begin{tabular}{|c|c|c|c|c|c|}
\hline Year & Reference & Country & Primate species ${ }^{a}$ & Diagnostic test & Prevalence (\%) \\
\hline 1962-1964 & Rudnick (1986) [23] & Malaysia & $\begin{array}{l}\text { Silvered leaf monkey } \\
\text { (Presbytis cristatus) }\end{array}$ & $\mathrm{HAl}$ and $\mathrm{SN}$ & $\begin{array}{l}66.7(26 / 39) \text { and } 47.8 \\
(30 / 63)\end{array}$ \\
\hline 1962-1964 & Rudnick (1986) [23] & Malaysia & $\begin{array}{l}\text { Crab-eating macaque } \\
\text { (cynomolgus monkey) } \\
\text { (Macaca fascicularis) }\end{array}$ & $\mathrm{HAl}$ and $\mathrm{SN}$ & $\begin{array}{l}92.8(64 / 69) \text { and } 68.7 \\
(106 / 154)\end{array}$ \\
\hline 1962-1964 & Rudnick (1986) [23] & Malaysia & $\begin{array}{l}\text { Southern pig-tailed } \\
\text { macaque (Macaca } \\
\text { nemestrina) }\end{array}$ & $\mathrm{HAl}$ and $\mathrm{SN}$ & $50.0(1 / 2)$ and $50.0(1 / 2)$ \\
\hline 1962-1964 & Rudnick (1986) [23] & Malaysia & $\begin{array}{l}\text { Sumatran surili (Presbytis } \\
\text { melalophos) }\end{array}$ & $\mathrm{HAl}$ and $\mathrm{SN}$ & $75.0(3 / 4)$ and $100(2 / 2)$ \\
\hline 1963-1966 and 1978 & Yuwono et al. (1984) [53] & $\begin{array}{l}\text { Japan (imported from } \\
\text { Indonesia and the } \\
\text { Philippines) }\end{array}$ & $\begin{array}{l}\text { Southeast Asian cyn- } \\
\text { omolgus (Macaca iris) }\end{array}$ & PRNT & $35.8(145 / 358)$ \\
\hline 1968 & Rudnick (1986) [23] & Malaysia & Unspecified & $\mathrm{Vl}$ & $100(1 / 1)$ \\
\hline $1969,1971-1972$ & $\begin{array}{l}\text { Fagbami et al. (1977) } \\
\text { [63] }\end{array}$ & Nigeria & Unspecified & $\mathrm{HAl}$ and $\mathrm{SN}$ & $48.9(45 / 92)$ \\
\hline $1969,1971-1972$ & $\begin{array}{l}\text { Fagbami et al. (1977) } \\
\text { [63] }\end{array}$ & Nigeria & Galagos & $\mathrm{HAl}$ and $\mathrm{SN}$ & $25.0(3 / 12)$ \\
\hline 1972 & Rudnick (1986) [23] & Malaysia & $\begin{array}{l}\text { Dusky leaf monkey } \\
\text { (Presbytis obscura) }\end{array}$ & $\mathrm{Vl}$ & $100(3 / 3)$ \\
\hline 1974-1982 & Saluzzo et al. (1986) [61] & Senegal & $\begin{array}{l}\text { Erythrocebus patas; Cer- } \\
\text { copithecus aethiops; } \\
\text { Papio papio }\end{array}$ & CFT & $2.5(10 / 395)$ \\
\hline 1982 & Cornet et al. (1984) [20] & Senegal & $\begin{array}{l}\text { Patas monkey (Eryth- } \\
\text { rocebus patas) }\end{array}$ & $\mathrm{Vl}$ & $0.4(1 / 250)$ \\
\hline 1986 & De Silva et al. (1999) [57] & Sri Lanka & $\begin{array}{l}\text { Toque macaque } \\
\text { (Macaca sinica) }\end{array}$ & ELISA & $12.5(2 / 16)$ \\
\hline 1987 & De Silva et al. (1999) [57] & Sri Lanka & $\begin{array}{l}\text { Toque macaque } \\
\text { (Macaca sinica) }\end{array}$ & ELISA & $93.2(41 / 44)$ \\
\hline 1987 & Peiris et al. (1993) [56] & Sri Lanka & $\begin{array}{l}\text { Toque macaque } \\
\text { (Macaca sinica) }\end{array}$ & PRNT & $94.1(64 / 68)$ \\
\hline $1991-2009$ & Kading et al. (2013) [26] & Gabon & $\begin{array}{l}\text { Mandrill (Mandrillus } \\
\text { sphinx) }\end{array}$ & PRNT & $8.0(2 / 25)$ \\
\hline 1995 & De Silva et al. (1999) [57] & Sri Lanka & $\begin{array}{l}\text { Toque macaque } \\
\text { (Macaca sinica) }\end{array}$ & ELISA & $21.3(52 / 244)$ \\
\hline 1996-1997 & Wolfe et al. (2001) [58] & Malaysia (Borneo) & $\begin{array}{l}\text { Orangutan (Pongo } \\
\text { pygmaeus) }\end{array}$ & PRNT & $29.6(21 / 71)$ \\
\hline 1999 & Inoue et al. (2003) [59] & The Philippines & $\begin{array}{l}\text { Cynomolgus (Macaca } \\
\text { fascicularis) }\end{array}$ & ELISA & $3.7(2 / 54)$ \\
\hline 2000 & Diallo et al. (2003) [29] & Senegal & $\begin{array}{l}\text { African green monkey } \\
\text { (Chlorocebus sabaeus) }\end{array}$ & ELISA & $58.8(10 / 17)$ \\
\hline $2006-2014$ & $\begin{array}{l}\text { Catenacci et al. (2018) } \\
\text { [67] }\end{array}$ & Brazil & $\begin{array}{l}\text { Golden-headed lion } \\
\text { tamarin (Leonto- } \\
\text { pithecus chrysomelas) }\end{array}$ & PRNT & $7.7(8 / 103)$ \\
\hline 2008-2009 & Nakgoi et al. (2014) [55] & Thailand & $\begin{array}{l}\text { Pig-tailed macaque } \\
\text { (Macaca nemestrina } \\
\text { leonine) }\end{array}$ & PRNT & $32.7(9 / 38)$ \\
\hline 2010 & Morales et al. (2017) [66] & Argentina & $\begin{array}{l}\text { Howler monkey } \\
\text { (Alouatta caraya) }\end{array}$ & PRNT & $1.8(2 / 108)$ \\
\hline 2010 & Kato et al. (2013) [42] & The Philippines & $\begin{array}{l}\text { Cynomolgus (Macaca } \\
\text { fascicularis) }\end{array}$ & ELISA; PRNT; and PCR & $\begin{array}{l}33.0(33 / 100) ; 22.9(8 / 35) \\
\quad \text { and } 42.8(3 / 7)\end{array}$ \\
\hline 2010,2012 & Hemme et al. (2016) [65] & USA (Puerto Rico) & $\begin{array}{l}\text { Patas monkey (Eryth- } \\
\text { rocebus patas) }\end{array}$ & PRNT & $100(21 / 21)$ \\
\hline 2010,2012 & Hemme et al. (2016) [65] & USA (Puerto Rico) & $\begin{array}{l}\text { Rhesus macaque } \\
\text { (Macaca mulatta) }\end{array}$ & PRNT & $100(2 / 2)$ \\
\hline
\end{tabular}


Table 2 (continued)

\begin{tabular}{|c|c|c|c|c|c|}
\hline Year & Reference & Country & Primate species ${ }^{a}$ & Diagnostic test & Prevalence (\%) \\
\hline 2013 & $\begin{array}{l}\text { Moreiro-Soto et al. } \\
\text { (2018) [77] }\end{array}$ & Brazil & $\begin{array}{l}\text { Red-handed howler } \\
\text { monkey (Alouatta } \\
\text { belzebul) }\end{array}$ & PRNT & $100(1 / 1)$ \\
\hline 2014 & $\begin{array}{l}\text { Eastwood et al. (2017) } \\
{[25]}\end{array}$ & Kenya & $\begin{array}{l}\text { Olive baboon (Papio } \\
\text { anubis) }\end{array}$ & ELISA & $57.1(4 / 7)$ \\
\hline 2014 & $\begin{array}{l}\text { Eastwood et al. (2017) } \\
{[25]}\end{array}$ & Kenya & $\begin{array}{l}\text { Yellow baboon (Papio } \\
\text { cynocephalus) }\end{array}$ & ELISA & $82.3(14 / 17)$ \\
\hline 2014 & $\begin{array}{l}\text { Moreiro-Soto et al. } \\
\text { (2018) [77] }\end{array}$ & Brazil & $\begin{array}{l}\text { Red-handed howler } \\
\text { monkey (Alouatta } \\
\text { belzebul) }\end{array}$ & PRNT & $100(1 / 1)$ \\
\hline
\end{tabular}

\footnotetext{
a As listed by the authors
}

Abbreviations: CFT, complement fixation test; ELISA, enzyme-linked immunosorbent assay; HAI, haemagglutination inhibition; PRNT, plaque reduction neutralisation testing; $\mathrm{PCR}$, polymerase chain reaction; $\mathrm{SN}$, serum neutralization; $\mathrm{VI}$, viral isolation

amphibians, reptiles, rodents, birds, insectivores and bats) and over 700 NHPs (Table 2) [23, 52]. After an initial survey from 1962 to 1964 (Table 2), substantial numbers of NHPs were found to have been exposed to DENV, being seropositive by HAI and/or PRNT and with seroconversion demonstrated in some cases (Table 2). While other vertebrate species were positive for antibodies by HAI, their sera failed to neutralise DENV indicating the presence of cross-reacting antibodies against, for example, Japanese encephalitis virus (JEV). Attempts to isolate DENV from mosquitoes, animal sera and tissues (liver, lung, spleen and heart) by inoculation into infant mice were initially only successful with a single NHP in 1968, representing the first recovery of DENV from a vertebrate other than man and later in 1972 from three sentinel dusky leafed monkeys (Presbytis obscura) (Table 2).

Experimental infections showed that NHPs could be infected with DENV although these animals showed no overt clinical signs. An immune-naïve, wild-caught NHP experimentally infected with a wild type DENV-4 (previously isolated from a NHP) developed DENV-4-specific neutralising antibodies although isolation attempts failed to demonstrate viraemia. Also, a NHP with neutralising antibodies against DENV-1, 2 and 3 became viraemic when infected with the wild type DENV-4 and produced antibodies de novo against DENV-4 and substantially increased antibodies against DENV-1, 2 and 3 indicating that although DENV-4 elicits a broadly reactive anti-DENV-1, 2 and 3 antibody response they are not cross-protective to DENV-4. Interestingly, four lorises (Nycticebus coucang) were refractory to wild type DENV-4 infection and did not develop antibodies or viraemia indicating that not all NHPs are equally susceptible to DENV.

Rudnick's studies [23] also included a comprehensive invertebrate survey, primarily targeting mosquitoes to determine their role in sylvatic cycles. Well over 500,000 mosquitoes (in excess of 69 species of 8 genera), representing the majority of species in Malaysia at that time, were collected from tree platforms in the canopy and at ground level using human landing collections, a variety of animal and $\mathrm{CO}_{2}$-baited traps, net traps and aspirators. DENV-2 and 4 were isolated from ground level $A e$. albopictus and DENV-4 from a group of six species of canopy-dwelling mosquitoes reported as Aedes niveus. The latter preferentially fed on NHPs when NHP-baited mosquito traps were placed in the forest canopy indicating the species' probable role in the sylvatic cycle. Ultimately, the study showed there was a sylvatic cycle in the forest canopy in the Malaysian peninsula with all four DENV serotypes circulating between NHPs and mosquitoes (most likely those in the Ae. niveus group).

\section{Dengue virus infections in NHPs in Southeast Asia}

Later serosurveys in Southeast Asia described seropositivity in NHPs from Indonesia, the Philippines, Cambodia, Vietnam and Malaysia [53], but not in NHPs originating from Japan (Table 2). Although mosquitoes were not studied, the data were regarded as suggesting sylvatic cycles might be widespread in Southeast Asia. Later, IgG, IgM, neutralising antibody and DENV RNA were demonstrated in cynomolgus macaques (Macaca fascicularis) in the Philippines, further suggesting natural cycling of infection in the region (Table 2) [42]. However, sequence analysis of the genes coding for the DENV nonstructural protein (NS1) and envelope (E) in isolates from two of the macaques showed they were the same as the circulating human/urban DENV strain. Infections were, then, most likely part of the urban cycle ('spillback' or 'reverse zoonosis') with NHPs having the potential to act as a reservoir of infection for epidemic/urban strains of the virus. The reverse event, 'spillover', was demonstrated to be possible in 2008 in Malaysia when the virus isolated from a man who contracted severe dengue after visiting 
Rudnick's field sites grouped into the same clade as Rudnick's original NHP isolates from 40 years previously [54]. Seropositive NHPs have been found in Thailand suggesting sylvatic cycles might occur there also (Table 2) [55] although there have been no sylvatic mosquito or viral characterisation studies.

There is now evidence that sylvatic cycles in Southeast Asia also occur on islands within the region. In Sri Lanka, almost all the NHPs studied in Polonnaruwa in 1987 had neutralising antibody to DENV-2 (Table 2) [56]. Further analysis revealed a highly focal epizootic of DENV had occurred in the population (Table 2) [57], which was not associated with a concurrent human outbreak. On the island of Borneo (Malaysia), nearly a third of wild and semi-captive orangutans (Pongo pygmaeus) sampled were seropositive to DENV-2 (Table 2) [58] and a few captive cynomolgus (Macaca fascicularis) on the nearby Luzon Island in the Philippines were IgM positive to DENV and all of them were IgG positive by ELISA against one or more flaviviruses (JEV and/or DENV) (Table 2) [59] suggesting a subacute primary infection or a reinfection.

\section{Dengue virus infections in NHPs and sylvatic mosquitoes in Africa}

Early evidence of a DENV sylvatic cycle in Africa can be found in a review of French publications resulting from work at the Institut Français de Recherche Scientifique pour le Développement en Coopération between 1972 and 1982 [60]. They reported isolating DENV-2 from a forest-dwelling mosquito, Aedes luteocephalus, in eastern Senegal in 1972 and because this mosquito was discovered far from human habitation, it was suggested that there might also be a sylvatic cycle of DENV in Africa.

In 1982, DENV-2 was isolated from a patas monkey (Erythrocebus patas) (Table 2) [20] in eastern Senegal. Further serological investigations (Table 2) [61] indicated there had been an amplification of DENV infections in local NHPs without a concurrent outbreak in the human population. Also, 28 viral isolations were made from forest-dwelling Ae. luteocephalus, Aedes taylori-furcifer, Aedes opok and Aedes africanus in the Ivory Coast [60] although there was no evidence of disease in the human population. Similar findings in forest-dwelling Aedes spp. in Burkina Faso and Guinea at around the same time added further evidence that these mosquitoes may be involved in a sylvatic cycle of DENV [60]. Ultimately, Rodhain [60] concluded that the studies he reviewed indicated a sylvatic cycle existed in West Africa comprising the patas monkey (E. patas) and most likely Ae. luteocephalus. The levels of infection varied with amplifications being seasonal, especially in times of high rainfall. However, 'spillover' into local human populations appeared uncommon with only one report of DENV-2 being isolated from local people and the sylvatic mosquitoes Ae. furcifer, Ae. taylori and Ae. luteocephalus in 1990 during a dengue epidemic [62].

Further support for the presence of sylvatic cycles in West Africa came from studies in remote forests of Nigeria where Fagbami et al. [63] (Table 2) reported high proportions of NHPs were seropositive against DENV. However, many were simultaneously positive against other flaviviruses indicating either co-circulation of multiple flaviviruses or broadly reactive antibody responses.

Following the initial isolation of DENV-2 from mosquitoes and NHPs in Kedougou, south-eastern Senegal, there have been ongoing comprehensive investigations of sylvatic arbovirus transmission cycles in the forests and savannah of the region $[8,12,29]$. A variety of seropositive NHPs have been reported (Table 2) and further DENV-2 isolates made in cell cultures (AP61; Aedes pseudoscuttelaris) from mosquitoes collected in the forest gallery, mainly Ae. furcifer, Ae. taylori, Ae. luteocephalus, Ae. aegypti and Ae. vittatus. The presence of infected mosquitoes and NHPs was regarded as evidence of a sylvatic cycle of DENV-2 existing in Senegal which involved AGMs in particular [29].

\section{Dengue virus infections in NHPs in Africa}

The recent findings of seropositive NHPs in Kenya (Table 2) [25] adds to the data on seropositive NHPs described in Senegal (Table 2) [29], Nigeria (Table 2) [63] and Gabon (Table 2) [26] and suggests the presence of sylvatic cycles is widespread in Africa.

\section{Dengue virus infections in NHPs in the Americas}

In the Americas, Rosen [64] found none of 105 NHPs sampled during an epidemic of dengue in people in Panama in 1941-1942 were seropositive against DENV, indicating a sylvatic dengue cycle was unlikely to be present at the time. Subsequently, between 2010 and 2012, wildcaught patas monkeys (E. patas) and rhesus macaques (Macaca mulatta) from Puerto Rico had serological evidence of prior DENV infection (Table 2) [65]. As there was no evidence for sylvatic cycling of DENVs in NHPs in the Americas, the authors suggested their results might represent 'spillback' infection, with the NHPs acquiring infections as part of urban cycles involving people on the islands. As viruses were not isolated, it was not possible to use phylogenetic characterisation to confirm the (urban) origin of the viruses.

In a survey in Argentina in 2010 (Table 2) [66], only a few free-ranging howler monkeys (Alouatta caraya) were seropositive solely to DENV-1 and 3 . This low level of infection was thought to result from 'spillback' from human infections rather than being evidence of a sylvatic cycle. Many other NHPs in the study had low magnitude 
seropositivity to DENV-1 and 3, which was thought to be due to multiple closely related flaviviruses infecting NHPs in a sylvatic environment. In the Bahia Atlantic Forest Reserve of Brazil between 2006 and 2014, low seropositivity to DENVs was found in free-living goldenheaded lion tamarins (Leontopithecus chrysomelas) that were proximate to agricultural workers thereby raising the possibility of 'spillback infection' (Table 2) [67].

\section{Dengue virus infections in sylvatic mosquitoes in the Americas}

There is little evidence of sylvatic cycles from mosquito studies with only a single putative isolation of DENV-1, not molecularly confirmed, from a rainforest-dwelling mosquito, Haemagogus leucocelaenus, near Brazil in 2002 [68].

\section{Summary}

Sylvatic cycles of DENVs involving NHPs have been shown to exist in Asia and Africa (Malaysia and Senegal), where DENV has been isolated from forest mosquitoes that feed on NHPs and from NHPs themselves. Serological data imply that sylvatic cycles may exist in the larger environs and islands of Southeast Asia and widely across Africa. There is no good evidence yet for sylvatic DENV circulation in NHPs in the Americas.

\section{Natural chikungunya virus infection in NHPs and mosquitoes}

Prior to 2004, the CHIKV was only known to produce localised outbreaks of disease (chikungunya fever) in Africa and Southeast Asia. Subsequently, there has been a near global spread of CHIKV to La Réunion, India, Asia and Europe reaching the Americas in December 2013, infecting millions of people [47]. Typical symptoms of infection include fever, myalgia, arthralgia, headaches and rashes and chronic arthritis. Rarely, more severe manifestations can include neurological disease, myocarditis and death. The CHIKV is an Alphavirus (Fig. 2), which occurs as three different genotypes [47].

\section{Chikungunya virus infections in NHPs and sylvatic mosquitoes in Africa}

McIntosh et al. [22] investigated possible sylvatic cycles of CHIKV in 1962 in Rhodesia (Zimbabwe) and discovered all the NHPs sampled were seropositive, although mosquitoes collected as part of the study, notably including the primatophilic Ae. furcifer-taylori, failed to yield virus.

In a wider study testing greater numbers of NHPs in South-West Africa (Namibia), South Africa (Cape Province, Orange Free State, Natal, Transvaal), Botswana, Zimbabwe (as Rhodesia) and Mozambique from 1964 to 1969 , the same species of NHP were also seropositive (Table 3) [69]. Analysis of the ages of the seropositive AGMs in Natal suggested a recent epizootic although none of the 42,000 mosquitoes tested contained CHIKV and no sentinel NHPs seroconverted [69]. The study indicated there was no active infection and NHPs were not currently maintaining sylvatic CHIKV although other arboviruses could be isolated from mosquitoes suggesting sylvatic transmission was viable in the region at that time [69]. In the forest canopies of Uganda (including Zika forest) in 1969, CHIKV was isolated from sylvatic mosquitoes Aedes africanus (9/102 pools; 8.8\%) and Mansonia (Mansonoides) fuscopennata (1/97 pools; $1.0 \%)$ accompanying high seropositivity in red-tailed monkeys (Cercopithecus ascanius schmidti) (Table 3) [70], consistent with an epizootic and probable sylvatic transmission.

In Senegal, between 1972 and 1983, CHIKV was isolated from multiple species of NHP (Table 2) [30]. Over the same period, CHIKV was detected in forest-dwelling mosquitoes using multiple tests. Between 1972 and 1986, Diallo et al. [30] isolated 178 strains of CHIKV, in cell cultures or mice, from 599,582 forest canopy mosquitoes, mainly Ae. furcifer-taylori (129/8244 pools; $1.6 \%)$, Ae. luteocephalus (27/3347 pools; 0.8\%) and Ae. dalzieli (12/2069 pools; $0.6 \%)$. A more detailed survey between 2009 and 2010 in the area (now considered a known focus of sylvatic arbovirus circulation due to previous CHIKV isolation in mosquitoes and NHPs) identified CHIKV by multiple tests in 15/50 species of mosquitoes captured [28] with 42 out of 4211 (10\%) pools of mosquitoes sampled (39,799 mosquitoes) were positive for CHIKV. Of these positive pools, 16 were Ae. furcifer (0.4\%), five were Ae. taylori (0.1\%), and five were Ae. luteocephalus (0.1\%). It was concluded that Ae. africanus, Ae. luteocephalus and Ae. furcifer-taylori (now recognised as two species: Ae. furcifer and Ae. taylori) were involved in the maintenance of the sylvatic cycle of CHIKV with Ae. furcifer most likely to contribute to any 'spillover' of infection to people. Shortly thereafter, when blood meals of the above species were analysed by PCR, only Ae. taylori was found to have fed on NHPs [32] indicating that blood meal host preferences vary between mosquito species and that species other than NHPs may be involved.

\section{Chikungunya virus infections in NHPs in Africa}

High seroprevalences have been recorded in multiple species of NHPs in Senegal, which have sometimes been associated with outbreaks in people (Table 3 ) [10, 71]. Of note, immediately after an outbreak of CHIKV in people in the region from 2010 to 2012 [10], high seropositivities were found in NHPs, especially juveniles. This was 
Table 3 Chronological arrangement of reports of laboratory confirmed natural infections of NHPs with CHIKV in countries around the world

\begin{tabular}{|c|c|c|c|c|c|}
\hline$\overline{Y e a r}$ & Reference & Country & Primate species $^{a}$ & Diagnostic test & Prevalence (\%) \\
\hline 1962 & Mclntosh et al. (1964) [22] & Zimbabwe $^{b}$ & Chacma baboon (Papio ursinis) & $\mathrm{HAl}$ and $\mathrm{VI}$ & $100(9 / 9)$ \\
\hline 1962 & McIntosh et al. (1964) [22] & Zimbabwe ${ }^{b}$ & $\begin{array}{l}\text { African green monkey (Chlo- } \\
\text { rocebus aethiops sabaeus) }\end{array}$ & $\mathrm{HAl}$ and $\mathrm{VI}$ & $100(4 / 4)$ \\
\hline $1965 ?$ & $\begin{array}{l}\text { Halstead \& Udomsakdi, (1966) } \\
\text { [73] }\end{array}$ & Thailand & Unspecified & $\mathrm{HAl}$ and $\mathrm{SN}$ & $\begin{array}{l}\text { Seropositive, numbers not } \\
\text { stated }\end{array}$ \\
\hline 1963-1967 & Marchette et al. (1978) [74] & Thailand & Macaca fascicularis & $\mathrm{HAl}$ and PRNT & $1.5(6 / 393)$ \\
\hline 1963-1967 & Marchette et al. (1978) [74] & Thailand & Macaca nemestrina & $\mathrm{HAl}$ and PRNT & $2.3(3 / 132)$ \\
\hline $1963-1967$ & Marchette et al. (1978) [74] & Thailand & Presbytis melalophos & $\mathrm{HAl}$ and PRNT & $16.7(1 / 6)$ \\
\hline 1963-1967 & Marchette et al. (1978) [74] & Thailand & Presbytis obscura & HAl and PRNT & $14.6(6 / 41)$ \\
\hline 1964-1969 & McIntosh (1970) [69] & South Africa (Transvaal) & Chacma baboon (Papio ursinis) & $\mathrm{HAl}$ and $\mathrm{SN}$ & $11.9(9 / 76)$ \\
\hline 1964-1969 & Mclntosh (1970) [69] & South Africa (Natal) & $\begin{array}{l}\text { African green monkey (Chlo- } \\
\text { rocebus aethiops sabaeus) }\end{array}$ & $\mathrm{HAl}$ and SN & $25.1(75 / 298)$ \\
\hline 1964-1969 & McIntosh (1970) [69] & Zimbabwe $^{b}$ & Chacma baboon (Papio ursinis) & HAl and SN & $100(4 / 4)$ \\
\hline 1969 & McCrae et al. (1971) [70] & Uganda & $\begin{array}{l}\text { Red-tailed monkey (Cerco- } \\
\text { pithecus ascanius schmidti) }\end{array}$ & $\mathrm{HAl}$ & $83.3(25 / 30)$ \\
\hline 1972 & Diallo et al. (1999) [30] & Senegal & $\begin{array}{l}\text { African green monkey (Cerco- } \\
\text { pithecus aethiops) }\end{array}$ & $\mathrm{VI}$ & $2 /$ not stated \\
\hline 1975 & Diallo et al. (1999) [30] & Senegal & Baboon (Papio papio) & $\mathrm{Vl}$ & $1 /$ not stated \\
\hline 1983 & Diallo et al. (1999) [30] & Senegal & $\begin{array}{l}\text { Patas monkey (Erythrocebus } \\
\text { patas) }\end{array}$ & $\mathrm{VI}$ & $1 /$ not stated \\
\hline $1985-2000$ & Eastwood et al. (2017) [25] & Kenya & Olive baboon (Papio anubis) & PRNT & $13.1(33 / 252)^{c}$ \\
\hline $1985-2000$ & Eastwood et al. (2017) [25] & Kenya & $\begin{array}{l}\text { Vervet monkey (Chlorocebus } \\
\text { aethiops) }\end{array}$ & PRNT & $13.1(33 / 252)^{c}$ \\
\hline $1985-2000$ & Eastwood et al. (2017) [25] & Kenya & $\begin{array}{l}\text { Blue monkey (Cercopithecus } \\
\text { mitis) }\end{array}$ & PRNT & $13.1(33 / 252)^{c}$ \\
\hline 1996 & Diallo et al. (1999) [30] & Senegal & $\begin{array}{l}\text { Bush baby (Galago senega- } \\
\text { lensis) }\end{array}$ & $\mathrm{Vl}$ & $1 /$ not stated \\
\hline 1996 & Diallo et al. (1999) [30] & Senegal & $\begin{array}{l}\text { African green monkey (Cerco- } \\
\text { pithecus aethiops) }\end{array}$ & $\mathrm{VI}$ & $1 /$ not stated \\
\hline 1998-2006 & Kading et al. (2013) [26] & Gabon & Mandrill (Mandrillus sphinx) & PRNT & $20.0(5 / 25)$ \\
\hline 2006 & Vourc'h et al. (2014) [72] & $\begin{array}{l}\text { Indian Ocean Islands } \\
\text { (Réunion, Mayotte, } \\
\text { Mauritius) }\end{array}$ & Brown lemur (Eulemurfulvus) & ELISA and PRNT & $3.8(2 / 52)$ \\
\hline 2006 & Vourc'h et al. (2014) [72] & $\begin{array}{l}\text { Indian Ocean Islands } \\
\text { (Réunion, Mayotte, } \\
\text { Mauritius) }\end{array}$ & $\begin{array}{l}\text { Crab-eating macaque (Macaca } \\
\text { fascicularis) }\end{array}$ & ELISA and PRNT & $1.5(2 / 134)$ \\
\hline 2007-2008 & Apandi et al. (2009) [75] & Malaysia & $\begin{array}{l}\text { Long-tailed macaque (Macaca } \\
\text { fascicularis) }\end{array}$ & $P C R$ & $3.8(4 / 105)$ \\
\hline 2008-2009 & Nakgoi et al. (2014) [55] & Thailand & $\begin{array}{l}\text { Northern pig-tailed macaque } \\
\text { (Macaca nemestrina leonine) }\end{array}$ & PRNT & $10.5(4 / 38)$ \\
\hline 2009-2010 & Sam et al. (2015) [76] & Malaysia & $\begin{array}{l}\text { Long-tailed macaque (Macaca } \\
\text { fascicularis) }\end{array}$ & PRNT & $0.7(1 / 146)$ \\
\hline 2009-2010 & Sow et al. (2018) [71] & Senegal & Guinea baboon (Papio papio) & PRNT & $82.0(96 / 117)$ \\
\hline 2009-2010 & Sow et al. (2018) [71] & Senegal & $\begin{array}{l}\text { African green monkey (Chlo- } \\
\text { rocebus sabaeus) }\end{array}$ & PRNT & $75.8(25 / 33)$ \\
\hline 2009-2010 & Sow et al. (2018) [71] & Senegal & $\begin{array}{l}\text { Patas monkey (Erythrocebus } \\
\text { patas) }\end{array}$ & PRNT & $7.0(5 / 71)$ \\
\hline 2010-2012 & Althouse et al. (2018) [10] & Senegal & Guinea baboon (Papio papio) & PRNT & $71.8(479 / 667)(n=399)^{c}$ \\
\hline 2010-2012 & Althouse et al. (2018) [10] & Senegal & $\begin{array}{l}\text { African green monkey (Chlo- } \\
\text { rocebus sabaeus) }\end{array}$ & PRNT & $71.8(479 / 667)(n=198)^{c}$ \\
\hline 2010-2012 & Althouse et al. (2018) [10] & Senegal & $\begin{array}{l}\text { Patas monkey (Erythrocebus } \\
\text { patas) }\end{array}$ & PRNT & $71.8(479 / 667)(n=70)^{c}$ \\
\hline 2013 & Moreiro-Soto et al. (2018) [77] & Brazil & $\begin{array}{l}\text { White-cheeked spider mon- } \\
\text { key (Ateles marginatus) }\end{array}$ & PRNT & $33.3(1 / 3)$ \\
\hline
\end{tabular}


Table 3 (continued)

\begin{tabular}{|c|c|c|c|c|c|}
\hline Year & Reference & Country & Primate species $^{a}$ & Diagnostic test & Prevalence (\%) \\
\hline 2013 & Moreiro-Soto et al. (2018) [77] & Brazil & $\begin{array}{l}\text { Common marmoset (Callithrix } \\
\text { jacchus) }\end{array}$ & PRNT & $12.5(1 / 8)$ \\
\hline 2013 & Moreiro-Soto et al. (2018) [77] & Brazil & $\begin{array}{l}\text { Capuchin monkey (Sapajus } \\
\text { sp.) }\end{array}$ & PRNT & $5.4(2 / 37)$ \\
\hline 2013 & Moreiro-Soto et al. (2018) [77] & Brazil & $\begin{array}{l}\text { Buff-headed capuchin (Sapa- } \\
\text { jus xanthosternos) }\end{array}$ & PRNT & $18.2(2 / 11)$ \\
\hline 2014 & Eastwood et al. (2017) [25] & Kenya & Olive baboon (Papio anubis) & PRNT & $27.8(5 / 18)$ \\
\hline 2014 & Eastwood et al. (2017) [25] & Kenya & $\begin{array}{l}\text { Red-tailed monkey (Cerco- } \\
\text { pithecus ascanius) }\end{array}$ & PRNT & $14.3(1 / 7)$ \\
\hline 2014 & Eastwood et al. (2017) [25] & Kenya & $\begin{array}{l}\text { Blue monkey (Cercopithecus } \\
\text { mitis) }\end{array}$ & PRNT & $37.5(3 / 8)$ \\
\hline 2014 & Moreiro-Soto et al. (2018) [77] & Brazil & $\begin{array}{l}\text { Blonde capuchin (Sapajus } \\
\text { flavius) }\end{array}$ & PRNT & $4.8(1 / 21)$ \\
\hline 2016 & Moreiro-Soto et al. (2018) [77] & Brazil & $\begin{array}{l}\text { Crested capuchin (Sapajus } \\
\text { robustus) }\end{array}$ & PRNT & $50.0(1 / 2)$ \\
\hline 2016 & Moreiro-Soto et al. (2018) [77] & Brazil & $\begin{array}{l}\text { Capuchin monkey (Sapajus } \\
\text { sp.) }\end{array}$ & PRNT & $14.3(3 / 21)$ \\
\hline
\end{tabular}

a As listed by the authors

b As Southern Rhodesia

c Distribution of results between NHP species not reported

Abbreviations: ELISA, enzyme-linked immunosorbent assay; HAl, haemagglutination inhibition; PRNT, plaque reduction neutralisation testing; PCR, polymerase chain reaction; $\mathrm{SN}$, serum neutralization; $\mathrm{VI}$, viral isolation

considered to indicate the presence of high herd immunity and that ongoing CHIKV circulation in a sylvatic cycle would be unlikely. There was thus the possibility that NHPs were not the only vertebrate hosts involved and alternate reservoirs of CHIKV were possible [10].

In Africa, then, there is strong evidence suggesting sylvatic cycles might occur in several species of NHPs across the continent. There is widespread evidence of exposure to CHIKV in a variety of NHPs across the continent in South Africa and Zimbabwe (Table 3) [22, 69], Uganda (Table 3) [70], Gabon (Table 3) [26] and Kenya (Table 3) [25], and CHIKV has been isolated from multiple species of NHPs [22, 30].

Off the coast of Africa, during the 2006 chikungunya epidemic on the French islands of La Réunion, Mayotte and Mauritius, approximately 266,000 people out of a total of 785,000 individuals were infected in La Réunion alone, but there was little serological evidence of infections in NHPs with only a few brown lemurs (Eulemur fulvus) and crab-eating macaques (Macaca fascicularis) found seropositive (Table 3) [72]. The brown lemurs (E. fulvus) were negative for CHIKV by PCR and it was thought the seropositive animals resulted from 'spillback' infections from people rather than as a result of the presence of a sylvatic cycle.

\section{Chikungunya virus infections in NHPs and sylvatic mosquitoes in Asia}

There are sparse data on sylvatic CHIKV in Asia. In rural Thailand in the 1960's, CHIKV was first isolated from a Culex tritaeniorhynchus and antibodies were reported in NHPs (Table 3) [73].

\section{Chikungunya virus infections in NHPs in Asia}

Further serological investigations of 1880 potential vertebrate hosts on the Malaysian peninsula between 1963 and 1967 included 642 NHPs, and only 16 (2.5\%) had antibodies to CHIKV (Table 3) [74]. The first isolation of CHIKV from NHPs in Asia was in Malaysia, from wild long-tailed macaques (Macaca fascicularis) sampled from 2007 to 2008; PCR and sequencing revealed the virus was distinct from the strain circulating in people at the time (Table 3) [75]. In a subsequent serosurvey the following year, shortly after a nationwide outbreak in people, the prevalence of neutralising antibodies in wild long-tailed macaques (M. fascicularis) was very low (1/146; 0.7\%) (Table 3) [76]. However, nearby in northern Thailand at about the same time, a higher percentage $(4 / 38 ; 10.5 \%)$ of captive northern pig-tailed macaques (Macaca nemestrina leonine) were found to be seropositive before and after CHIKV activity in people in the region suggesting macaques could become infected by CHIKV independently of people (Table 3) [55]. Finally, on the Island of Borneo (Malaysia) wild and semi-captive orangutans (Pongo pygmaeus) were seronegative 
to CHIKV [58] indicating that sylvatic CHIKV may not infect this species or the virus might not have spread to islands in the region.

\section{Chikungunya virus infections in NHPs in the Americas}

The CHIKV was introduced into the Americas in 2013 and 2014 and as the epidemic progressed, it was speculated that there was a risk of the virus establishing a sylvatic cycle in New World NHPs, as YFV had done previously. Investigations of sylvatic cycles have been limited and confined to Brazil [77] where several species of NHP were sampled between 2012 and 2017 and found to have very low seropositivity to CHIKV with very low antibody titres (Table 3) [77]. Two of the NHPs were also MAYV positive by PRNT highlighting the difficulty in interpreting serology in the presence of cross-reactivity. None had detectable CHIKV RNA by RT-PCR indicating an absence of active infection [77].

\section{Summary}

In Africa (Uganda and Senegal), CHIKV has been isolated from forest mosquitoes and NHPs and seropositive NHPs are common and widespread, providing good evidence for the presence of sylvatic transmission cycles. However, it is unclear if NHPs are the only vertebrate host of CHIKV or if there is a role for other vertebrates in the maintenance of the virus. In Asia, a sylvatic cycle has not been demonstrated as there is no evidence of CHIKV in forest-dwelling mosquitoes and CHIKV infections are not common or widespread in NHPs. Similarly, in the Americas, although investigations have been limited, there is only weak serological data suggesting sylvatic cycles, although it has been suggested they might yet become established due to the high numbers of susceptible mosquitoes, NHPs and people. [77-80].

\section{Natural infections of Zika virus in NHPs and mosquitoes}

The ZIKV is endemic in Africa and Asia [47] but caused a global epidemic when it spread to Yap Island in Micronesia in 2007 and eventually through the Pacific islands to the Americas by 2015. Infections in people can be asymptomatic or result in mild fever, rash, arthritis, arthralgia and myalgia. Infections have been linked with GuillainBarré syndrome and severe birth defects in babies born to women infected while pregnant. The ZIKV is a Flavivirus (Fig. 2) and there are three distinct genotypes [47].

\section{Zika virus infections in NHPs and sylvatic mosquitoes in Africa}

The ZIKV was first identified in 1947 in the Zika (syn. Ziika) forest of Uganda (Table 4) [21] when, as part of a YFV surveillance project, the ZIKV was isolated from a sentinel rhesus macaque (Macaca mulatta) and the local sylvatic YFV vector, Ae. africanus. This provided evidence of a sylvatic circulation of the virus in NHPs and mosquitoes that feed on them. More extensive investigations in the region in the late 1960's found high seropositivity in several NHP species (Table 4) [81] and led to the isolation of ZIKV from Ae. africanus (14/27 pools; 51.8\%) and Aedes apicoargenteus (1/1 pool; 100\%) [81]. Due to the extensive arboviral investigations and periodic YFV and CHIKV activity in the NHPs and mosquitoes, researchers began to suggest the possibility of cross-protection (immunisation) between YFV and ZIKV (and possibly CHIKV) in NHPs. It was also suggested that successive arboviral infection (flaviviruses and alphaviruses) of mosquitoes may interfere with their ability to transmit virus [81]. In 1968 in Senegal, the ZIKV was first isolated from Ae. luteocephalus from the Saboya forest and in 1980 the ZIKV was also isolated from NHPs (Table 4) $[8,9,16]$.

\section{Zika virus infections in sylvatic mosquitoes in Africa}

Subsequent investigations of mosquitoes in forests and forest canopies have identified further species naturally infected with ZIKV: Ae. opok in the Central African Republic; Ae. luteocephalus in Nigeria; and Ae. vittatus, Ae. furcifer and Ae. aegypti formosus in the Ivory Coast and Senegal [82]. It is assumed that because these species were collected in remote forest areas, away from human habitation, transmission of ZIKV is primarily sylvatic involving NHPs, although the possibility of vertical transmission could not be excluded [83].

\section{Zika virus infections in NHPs in Africa}

As the recent ZIKV pandemic developed, serological evidence of natural infections of ZIKV were described in a wide variety of NHPs from across Africa including Uganda, Nigeria, Gambia and Tanzania (Table 4) [45, 47, 84-86].

\section{Zika virus infections in NHPs and sylvatic mosquitoes in Asia}

In Asia, there have been only limited studies of possible ZIKV vectors $[87,88]$ despite the widespread but benign circulation of ZIKV in people for decades [89]. Marchette et al. [90] investigated potential sylvatic mosquito vectors across Malaysia and despite analysing 27,636 Aedes spp. mosquitoes from rural areas, rain forests, mangrove swamps and freshwater swamps, they only managed to isolate ZIKV from urban Ae. aegypti. Interestingly, the authors state "there is strong serological evidence that 
Table 4 Chronological arrangement of reports of laboratory confirmed natural infection of NHPs with ZIKV in countries around the world

\begin{tabular}{|c|c|c|c|c|c|}
\hline Year & Reference & Country & Primate species ${ }^{a}$ & Diagnostic test & Prevalence (\%) \\
\hline 1947 & Dick et al. (1952) [21] & Uganda & Rhesus macaque (Macaca mulatta) & $\mathrm{Vl}$ & $100(1 / 1)$ \\
\hline 1962-1971 & Rudnick (1986) [23] & Malaysia & Pig-tailed macaque (Macaca nemestrina) & $\mathrm{HAl}$ & $1.2(2 / 163)$ \\
\hline 1962-1971 & Rudnick (1986) [23] & Malaysia & Long-tailed macaque (Macaca fascicularis) & $\mathrm{HAl}$ & $1.8(4 / 225)$ \\
\hline 1969-1970 & McCrae \& Kirya (1982) [81] & Uganda & $\begin{array}{l}\text { Red-tailed monkey (Cercopithecus ascanius } \\
\text { schmidti) }\end{array}$ & $\mathrm{HAl}$ and $\mathrm{SN}$ & $38.1(54 / 142)$ and $52.1(74 / 142)$ \\
\hline 1969-1970 & McCrae \& Kirya (1982) [81] & Uganda & Colobus (Colobus abyssinicus uellensis) & $\mathrm{HAl}$ and $\mathrm{SN}$ & $45.4(5 / 11)$ and $54.5(6 / 11)$ \\
\hline 1969-1970 & McCrae \& Kirya (1982) [81] & Uganda & Mangabey (Cercocebus albigena johnstoni) & $\mathrm{HAl}$ and $\mathrm{SN}$ & $50.0(2 / 4)$ and $75(3 / 4)$ \\
\hline 1969-1971 & Monath \& Kemp (1973) [45] & Nigeria & African green monkey (Chlorocebus aethiops) & $\mathrm{HAl}$ and $\mathrm{SN}$ & $55.5(5 / 9)$ and $66.6(6 / 9)$ \\
\hline 1969-1971 & Monath \& Kemp (1973) [45] & Nigeria & Mona monkey (Cercopithecus mona) & $\mathrm{HAl}$ and $\mathrm{SN}$ & $36.1(13 / 36)$ and $41.7(15 / 36)$ \\
\hline 1969-1971 & Monath \& Kemp (1973) [45] & Nigeria & $\begin{array}{l}\text { Western putty-nosed monkey (Cercopithecus } \\
\text { nictitans martini) }\end{array}$ & $\mathrm{HAl}$ and $\mathrm{SN}$ & $50.0(2 / 4)$ and $25.0(1 / 4)$ \\
\hline 1969-1971 & Monath \& Kemp (1973) [45] & Nigeria & $\begin{array}{l}\text { Red-capped mangabey (Cercopithecus } \\
\text { torquatus) }\end{array}$ & $\mathrm{HAl}$ and $\mathrm{SN}$ & $100(5 / 5)$ and $80.0(4 / 5)$ \\
\hline 1969-1971 & Monath \& Kemp (1973) [45] & Nigeria & Olive baboon (Papio anubis choras) & $\mathrm{HAl}$ and $\mathrm{SN}$ & $100(2 / 2)$ and $50.0(1 / 2)$ \\
\hline 1969-1971 & Monath \& Kemp (1973) [45] & Nigeria & Wadi monkey (Erythrocebus patas) & $\mathrm{HAl}$ and $\mathrm{SN}$ & $11.9(8 / 67)$ and $5.9(4 / 67)$ \\
\hline 1979-1980 & Althouse et al. (2015) [8] & Senegal & Vervet monkey (Chlorocebus aethiops) & $\mathrm{VI}$ and IFA & $100(1 / 1)$ and $100(1 / 1)$ \\
\hline 1980 & Althouse et al. (2015) [8] & Senegal & Patas monkey (Erythrocebus patas) & $\mathrm{VI}$ and IFA & $100(1 / 1)$ and $100(1 / 1)$ \\
\hline 1985,1986 & Buechler et al. (2016) [84] & Gambia & Vervet monkey (Chlorocebus sp.) & ELISA & $16.0(4 / 25)$ \\
\hline 1996-1998 & Kilbourn et al. (2003) [91] & Malaysia & $\begin{array}{l}\text { Western Bornean orangutan (Pongo pyg- } \\
\text { maeus pygmaeus) }\end{array}$ & ELISA and/or IFA & $8.4(6 / 71)$ \\
\hline 1996-1997 & Wolfe et al. (2001) [58] & Malaysia & $\begin{array}{l}\text { Western Bornean orangutan (Pongo pyg- } \\
\text { maeus pygmaeus) }\end{array}$ & PRNT & $2.8(2 / 71)$ \\
\hline 2010-2014 & Buechler et al. (2016) [84] & Tanzania & Yellow baboon (Papio sp.) & ELISA & $4.9(2 / 41)$ \\
\hline 2012 & Moreiro-Soto et al. (2018) [77] & Brazil & Capuchin (Sapajus sp.) & PRNT & $4.8(1 / 21)$ \\
\hline 2012 & Moreiro-Soto et al. (2018) [77] & Brazil & Marmoset (Callithrix penicillata) & PRNT & $100(1 / 1)$ \\
\hline 2013 & Moreiro-Soto et al. (2018) [77] & Brazil & $\begin{array}{l}\text { Red-handed howler monkey (Alouatta } \\
\text { belzebul) }\end{array}$ & PRNT & $100(1 / 1)$ \\
\hline 2014 & Moreiro-Soto et al. (2018) [77] & Brazil & Capuchin (Sapajus flavius) & PRNT & $4.8(1 / 21)$ \\
\hline 2014 & Moreiro-Soto et al. (2018) [77] & Brazil & $\begin{array}{l}\text { Red-handed howler monkey (Alouatta } \\
\text { belzebul) }\end{array}$ & PRNT & $100(1 / 1)$ \\
\hline 2016 & Favoretto et al. (2016) [92] & Brazil & Capuchin (Sapajus libidinosus) & $P C R$ & $33.3(3 / 9)$ \\
\hline 2016 & Favoretto et al. (2016) [92] & Brazil & Marmoset (Callithrix jacchus) & PCR & $26.7(4 / 15)$ \\
\hline 2017 & Terzian et al. (2018) [93] & Brazil & Capuchin (Sapajus libidinosus) & $P C R$ & $38.2(31 / 81)$ \\
\hline 2017 & Terzian et al. (2018) [93] & Brazil & Marmoset (Callithrix jacchus) & $P C R$ & $100(1 / 1)$ \\
\hline 2017 & Moreiro-Soto et al. (2018) [77] & Brazil & $\begin{array}{l}\text { Red-handed howler monkey (Alouatta } \\
\text { belzebul) }\end{array}$ & PRNT & $33.3(1 / 3)$ \\
\hline
\end{tabular}

\footnotetext{
a As listed by the authors
}

Abbreviations: ELISA, enzyme-linked immunosorbent assay; HAI, haemagglutination inhibition; IFA, immunofluorescence antibody test; PRNT, plaque reduction neutralisation testing; $\mathrm{PCR}$, polymerase chain reaction; $\mathrm{SN}$, serum neutralization; $\mathrm{Vl}$, viral isolation

it (ZIKV) occurs naturally in wild monkeys in Malaysia (our unpublished data)".

\section{Zika virus infections in NHPs in Asia}

The only published data on NHPs revealed ZIKV seropositive individuals in a small focus of captive and semiwild orangutans (Pongo pygmaeus) in Borneo, Malaysia, which was thought to represent 'spillback' from infected people (Table 4) [58, 91].

\section{Zika virus infections in NHPs in the Americas}

In the Americas, 'spillback' infection from people to peri-urban capuchins (Sapajus libidinosus) and marmosets (Callithrix jacchus) in two cities in Brazil was suspected to be the reason for several ZIKV RT-PCRpositive NHPs found in 2016 and 2017 during the large human epidemic (Table 4) [92, 93]. This finding rekindled speculation that a sylvatic cycle of ZIKV could become established. More extensive studies around Brazil, however, failed to identify ZIKV RNA by PCR and found only 
low seroprevalences and antibody titres to ZIKV, which were thought to indicate an absence of established sylvatic cycles (Table 4) [77].

\section{Summary}

Sylvatic cycles of ZIKV exist in Africa (Uganda and Senegal) with virus having been isolated from forest-dwelling mosquitoes and NHPs which appear to be commonly infected based on widespread seropositivity. Sylvatic cycles appear to be absent in Asia but there are limited data for this region. Currently, sylvatic cycles of ZIKV have not been conclusively demonstrated in the Americas; however, multiple examples of 'spillback' infection are documented and there is thus a possibility for sylvatic cycles to develop $[9,82]$.

\section{Natural yellow fever virus infections in NHPs and mosquitoes}

The history and role of NHPs in the epidemiology of YFV around the world is well documented $[3,6,60,94]$ and the early investigations into the epidemiology of YFV led to the development of the concepts of arboviral sylvatic cycles in NHPs that we have today $[13,94]$. Yellow fever outbreaks continue in Africa and South America and can be extensive. Most YFV infections in people are subclinical but signs can range from mild fever, myalgia, headache and nausea with a rapid recovery to high fever, abdominal pain, jaundice, hepatitis, haemorrhagic diatheses and death [47]. The YFV is the archetypal Flavivirus and exists in seven genotypes [6].

\section{Yellow fever infection in NHPs and mosquitoes in Africa}

YFV originated in Africa in a sylvatic cycle involving a wide range of NHPs including baboons (Papio spp.), colobus monkeys (Colobus spp.), green and vervet monkeys (Cercopithecus spp.), mangabeys (Cercocebus spp.), chimpanzees (Pan troglodytes), bush babies (Galago spp.) and forest-dwelling mosquitoes (Aedes bromeliae, Ae. taylori, Ae. africanus, Ae. luteocephalus, Aedes metallicus, Ae. opok, Ae. vittatus and the Aedes simpsoni complex) $[3,82]$.

\section{Yellow fever infection in NHPs and mosquitoes in the Americas}

The YFV was introduced into people in the Americas during the slave trade with West Africa 400 years ago [3]. Sylvatic cycles developed in South America as local NHPs became infected, mainly howler monkeys (Alouatta spp.), squirrel monkeys (Saimiri spp.), spider monkeys (Ateles spp.) and owl monkeys (Aotus spp.). Transmission of the YFV in the NHPs was established by infection of local mosquitoes that were capable of transmitting the YFV, mainly Haemagogus albomaculatus, Haemagogus spegazzini, Haemagogus janthinomys, Sabethes chloropterus, Sabethes albipivus, Sabethes glaucodaemon, Sabethes soperi and Sabethes cyaneus [3, 82].

Unlike the situation with NHPs in Africa, native South American species of NHP are susceptible to YFV, developing clinical signs and often dying from infections. Indeed, today nearly all human outbreaks of YFV in South America and Africa result from 'spillover' infection from NHPs, and deaths in South American NHPs are now a well-known warning sign of YFV amplification and the heralding of a yellow fever outbreak in local people $[3,6,82]$.

\section{Yellow fever infection in NHPs and mosquitoes in Asia}

Yellow fever is notably absent from Asia despite there being large numbers of susceptible people, mosquitoes that can transmit the virus, and native NHPs that have been found to be highly susceptible to experimental infections with YFV [6]. Possible reasons for the absence of observed disease in people have been reviewed [3] and include the lack of opportunity for the YFV to spread with the lack of major trade routes between West Africa and Asia and the fact that YFV has not been documented in nearby East Africa. It might also result from lack of surveillance and the similar clinical presentation of yellow fever and dengue, which is a very common disease in Asia. Additionally, DENV antibodies in NHP hosts and people might provide cross-protection against the YFV and there might be direct viral competition between the viruses in mosquitoes. There is also the unlikely possibility that Asian Aedes spp. cannot transmit YFV.

\section{Future threats}

Several other mosquito-borne viruses that produce disease in people are suspected to be sustained in nature by sylvatic cycles involving NHPs and/or other vertebrates. Presently, they appear localised and to cause little human disease but have the potential for geographical expansion with changes in climate, mosquito distribution, viral genomic drift, and encroachment of people into the sylvatic habitats $[3-5,13,47]$. The putative involvement of NHPs in the sylvatic transmission of these viruses is largely based on retrospective serological investigations with all their limitations.

\section{Mayaro virus}

MAYV (Alphavirus) was first discovered in a group of rural workers in Trinidad in 1954 [95] and subsequently reported to occur in a sylvatic cycle in South America, probably involving NHPs and forest mosquitoes (Haemagogus spp.). The virus, however, has never been isolated from an NHP and the definitive reservoir host is still unproven with antibodies having been detected in 
many vertebrates $[96,97]$. In Panama, a high prevalence of neutralising antibodies was reported in howler monkeys (Alouatta villosa) [97], and in French Guiana, antiMAYV HAI antibodies have been detected in red howler monkeys (Alouatta seniculus) (70/106; 66\%) and goldenhanded tamarins (Saguinus midas) (8/44; 18\%) [98]. Subsequently, they were found again in red howler monkeys (A. seniculus) and golden-handed tamarins (S. midas) $(19 / 42 ; 50 \%)$ in addition to $(52 / 98 ; 53 \%)$, white-faced saki (Pithecia pithecia) $(5 / 80 ; 6 \%)$ and squirrel monkeys (Saimiri sciureus) (6/67; 9\%) [96]. More recent studies in Brazil in 2010 and 2014, have demonstrated anti-MAYV HAI antibody in free-living capuchins (Sapajus spp.) [41, 99], black howler monkeys (Alouatta caraya) [41] and captive NHPs [black howler monkeys (Alouatta caraya), white-eared titis (Callicebus donacophilus) and tufted capuchins (Cebus apella)] [40]. There may also be alternate or additional non-primate vertebrate hosts, and it has been suggested that MAYV is introduced into canopy-dwelling NHPs by migratory birds [40]. This might account for higher serological evidence of infection in NHPs more active in tree canopies [96].

\section{Oropouche virus}

Oropouche virus (OROV) (Orthobunyavirus) causes Oropouche fever in people and has been responsible for large epidemics (second only to dengue) in Brazil, Peru, Panama, and Trinidad and Tobago where it was initially isolated from a forest worker in 1955 [100]. The OROV exists in a sylvatic cycle reportedly involving the mosquito species Coquillettidia venezuelensis, Aedes serratus, Culex quinquefasciatus, Ochlerotatus serratus and midges of the genus Culicoides. A vertebrate host has not been established, but there is a single report of isolation of OROV from a marmoset in Brazil (Callithrix sp.) [101] and a sloth (Bradypus tridactylus) in a 1960 report. A few free-living and captive NHPs in Brazil have been found seropositive [40, 41], as have capuchin monkeys (Sapajus spp.), black-and-gold howler monkeys (A. caraya), black-tufted marmosets (Callithrix penicillata) and other vertebrates including pale-throated three-toed sloths (Bradypus tridactylus), rodents (Proechimys spp.), and birds (Fringillidae, Thaurapidae, Columbidae) [100].

\section{O'nyong'nyong virus}

O'nyong'nyong virus (Alphavirus), the agent of o'nyong'nyong fever, is endemic in sub-Saharan Africa and was first isolated during an epidemic in Uganda in 1959 [102]. It is unique among mosquito borne alphaviruses as it is transmitted by night-feeding African anopheline mosquitoes (Anopheles funestus and Anopheles gambiae). The vertebrate host in the enzootic cycle is unknown; however, mandrills in Gabon $(4 / 25 ; 16 \%)$ have been found seropositive to ONNV by PRNT [102].

\section{Spondweni virus}

Spondweni virus (SPONV) (Flavivirus) is closely related to ZIKV and is the agent of Spondweni fever in people in Africa, which is readily confused with Zika [103]. It has been isolated from several species of mosquito, most significantly from the African forest-dwelling Aedes circumluteolus [94], but the vertebrate host is unknown. Although previously not thought to exist outside of Africa, SPONV was recently isolated from Culex spp. mosquitoes collected in Haiti in 2016 [103].

\section{Lumbo virus}

Lumbo virus (LUMV) (bunyavirus) [47] was isolated from Aedes pembaensis in Mozambique 1959 and 1960 during investigations into arboviruses in people. Although people have been found to have neutralizing antibodies against the virus, it is not known to cause clinical disease. Experimental infections of three individual NHPs, a vervet monkey (Cercopithecus aethiops pygerythrus), yellow baboon (Papio cynocephalus) and bush baby (Galago crassicaudatus), resulted in seroconversion and significantly viraemia in the vervet monkey, but no clinical illness [104]. Oddly, outside of Africa, 14/115 (12\%) toque macaques in Thailand had LUMV neutralising antibodies [5].

\section{Conclusions}

The literature reviewed in this paper shows that: (i) there are many methods that can be used to identify NHPs and mosquitoes that are important in sylvatic cycles; (ii) there is clear evidence that sylvatic cycles occur in Africa and Asia; mostly these involve NHPs but the role of other forest-dwelling animals must not be overlooked; (iii) there are other arboviruses which might pose future threats to global public health and which might occur in sylvatic cycles with NHPs.

\section{Abbreviations}

CHIKV: chikungunya virus; CFT: complement fixation test; DENV: dengue virus; ELISA: enzyme-linked immunosorbent assay; HAl: haemagglutination inhibition; IgG: immunoglobulin G; IgM: immunoglobulin M; IFA: immunofluorescence antibody test; JEV: Japanese encephalitis virus; LUMV: Lumbo virus; MAYV: Mayaro virus; NHP: non-human primate; ONNV: o'nyong'nyong virus; OROV: Oropouche virus; PRNT: plaque reduction neutralisation testing; PCR: polymerase chain reaction; SN: serum neutralization; SPOV: Spondweni virus; VI: viral isolation; ZIKV: Zika virus.

Authors' contributions

MJV prepared the data tables. PJK and MJV prepared the manuscript text. CCM reviewed the manuscript. All authors read and approved the final manuscript. 


\section{Funding}

MJV's stipend as a PhD student was partly funded by the National Institute of Allergy and Infectious Diseases grant number 1R21Al128407-01 and the Ross University School of Veterinary Medicine.

\section{Availability of data and materials}

Not applicable.

\section{Ethics approval and consent to participate}

Not applicable.

\section{Consent for publication}

Not applicable.

\section{Competing interests}

The authors declare that they have no competing interests.

\begin{abstract}
Author details
${ }^{1}$ One Health Centre for Zoonoses and Tropical Veterinary Medicine, Ross University School of Veterinary Medicine, Island Main Road, West Farm, Basseterre, Saint Kitts and Nevis. ${ }^{2}$ Center for the Ecology of Infectious Diseases, University of Georgia, Athens, GA, USA. ${ }^{3}$ Odum School of Ecology, University of Georgia, Athens, GA, USA. ${ }^{4}$ Department of Infectious Diseases, University of Georgia, Athens, GA, USA. ${ }^{5}$ Center for Tropical and Global Emerging Diseases, University of Georgia, Athens, GA, USA. ${ }^{6}$ Department of Clinical Sciences, Ross University School of Veterinary Medicine, Island Main Road, West Farm, Basseterre, Saint Kitts and Nevis.
\end{abstract}

Received: 3 May 2019 Accepted: 25 September 2019 Published online: 02 October 2019

\section{References}

1. Jones KE, Patel NG, Levy MA, Storeygard A, Balk D, Gittleman JL, et al. Global trends in emerging infectious diseases. Nature. 2008;451:990-3.

2. Weaver SC, Barrett ADT. Transmission cycles, host range, evolution and emergence of arboviral disease. Nat Rev Microbiol. 2004;2:789-801.

3. Hanley KA, Monath TP, Weaver SC, Rossi SL, Richman RL, Vasilakis N. Fever versus fever: the role of host and vector susceptibility and interspecific competition in shaping the current and future distributions of the sylvatic cycles of dengue virus and yellow fever virus. Infect Genet Evol. 2013;19:292-311.

4. Vasilakis N, Cardosa J, Hanley KA, Holmes EC, Weaver SC. Fever from the forest: prospects for the continued emergence of sylvatic dengue virus and its impact on public health. Nat Rev Microbiol. 2011;9:532-41.

5. Weaver SC. Host range, amplification and arboviral disease emergence. Arch Virol Suppl. 2005;19:33-44.

6. Chippaux JP, Chippaux A. Yellow fever in Africa and the Americas: a historical and epidemiological perspective. J Venom Anim Toxins Incl Trop Dis. 2018;24:20

7. Musso D, Gubler DJ. Zika virus. Clin Microbiol Rev. 2016;29:487-524.

8. Althouse BM, Hanley KA, Diallo M, Sall AA, Ba Y, Faye O, et al. Impact of climate and mosquito vector abundance on sylvatic arbovirus circulation dynamics in Senegal. Am J Trop Med Hyg. 2015;92:88-97.

9. Althouse BM, Vasilakis N, Sall AA, Diallo M, Weaver SC, Hanley KA. Potential for Zika virus to establish a sylvatic transmission cycle in the Americas. PLoS Negl Trop Dis. 2016;10:e0005055.

10. Althouse BM, Guerbois M, Cummings DAT, Diop OM, Faye O, Faye A, et al. Role of monkeys in the sylvatic cycle of chikungunya virus in Senegal. Nat Commun. 2018;9:1046.

11. Weaver SC, Vasilakis N. Molecular evolution of dengue viruses: contributions of phylogenetics to understanding the history and epidemiology of the preeminent arboviral disease. Infect Genet Evol. 2009;9:523-40.

12. Althouse BM, Lessler J, Sall AA, Diallo M, Hanley KA, Watts DM, et al. Synchrony of sylvatic dengue isolations: a multi-host, multi-vector SIR model of dengue virus transmission in Senegal. PLoS Negl Trop Dis. 2012;611:e1928.

13. Kuno G, Mackenzie JS, Junglen S, Plyusnin A, Gubler DJ. Vertebrate reservoirs of arboviruses: myth, synonym of amplifier, or reality? Viruses. 2017:9:185.
14. Higgs S, Ziegler SA. A nonhuman primate model of chikungunya disease. J Clin Invest. 2010;120:657-60.

15. Kuno G, Chang GJ. Biological transmission of arboviruses: reexamination of and new insights into components, mechanisms, and unique traits as well as their evolutionary trends. Clin Microbiol Rev. 2005;18:608-37.

16. Althouse BM, Durbin AP, Hanley KA, Halstead SB, Weaver SC, Cummings DA. Viral kinetics of primary dengue virus infection in non-human primates: a systematic review and individual pooled analysis. Virology. 2014;452-453:237-46.

17. Hanley KA, Guerbois M, Kautz TF, Brown M, Whitehead SS, Weaver SC, et al. Infection dynamics of sylvatic dengue virus in a natural primate host, the African green monkey. Am J Trop Med Hyg. 2014;91:672-6.

18. Chen Cl, Clark DC, Pesavento P, Lerche NW, Luciw PA, Reisen WK, et al. Comparative pathogenesis of epidemic and enzootic chikungunya viruses in a pregnant Rhesus macaque model. Am J Trop Med Hyg. 2010;83:1249-58.

19. Dudley DM, Aliota MT, Mohr EL, Weiler AM, Lehrer-Brey G, Weisgrau KL, et al. A rhesus macaque model of Asian-lineage Zika virus infection. Nat Commun. 2016;7:12204

20. Cornet M, Saluzzo JF, Hervy JP, Digoutte JP, Germain M, Chauvancy MF, et al. Dengue 2 au Sénégal oriental: une pousse épizootique en milieu selvatique; isolements du virus à partir de moustiques et d'un singe et considérations épidémiologiques. Cah ORSTOM Ser Ent Med Parasitol. 1984;22:313-23.

21. Dick GW, Kitchen SF, Haddow AJ. Zika Virus (I). Isolations and serological specificity. Trans R Soc Trop Med Hyg. 1952;46:509-20.

22. McIntosh BM, Paterson HE, Mcgillivray G, Desousa J. Further studies on the chikungunya outbreak in southern Rhodesia in 1962. I. Mosquitoes, wild primates and birds in relation to the epidemic. Ann Trop Med Parasitol. 1964:58:45-51.

23. Rudnick A. Dengue virus ecology in Malaysia. Inst Med Res Malays Bull. 1986:23:51-152.

24. Weinbren MP, Haddow AJ, Williams MC. The occurrence of chikungunya virus in Uganda I. Isolation from mosquitoes. Trans R Soc Trop Med Hyg. 1958:52:253-62.

25. Eastwood G, Sang RC, Guerbois M, Taracha ELN, Weaver SC. Enzootic circulation of chikungunya virus in East Africa: serological evidence in non-human Kenyan primates. Am J Trop Med Hyg. 2017;97:1399-404.

26. Kading RC, Borland EM, Cranfield M. Prevalence of antibodies to alphaviruses and flaviviruses in free-ranging game animals and nonhuman primates in the greater Congo basin. J Wild Dis. 2013:49:587-99.

27. Silver JB. Mosquito ecology: field sampling methods. 3rd ed. London: Springer; 2008.

28. Diallo D, Sall AA, Buenemann M, Chen R, Faye O, Diagne CT, et al. Landscape ecology of sylvatic chikungunya virus and mosquito vectors in southeastern Senegal. PLoS Negl Trop Dis. 2012;6:e1649.

29. Diallo M, Ba Y, Sall AA, Diop OM, Ndione JA, Mondo M, et al. Amplification of the sylvatic cycle of dengue virus type 2, Senegal, 1999-2000: entomologic findings and epidemiologic considerations. Emerg Infect Dis. 2003:9:362-7.

30. Diallo M, Thonnon J, Traore-Lamizana M, Fontenille D. Vectors of chikungunya virus in Senegal: current data and transmission cycles. Am J Trop Med Hyg. 1999;60:281-6.

31. Maciel-de-Freitas R, Neto RB, Gonçalves JM, Codeço CT, Lourenço-deOliveira R. Movement of dengue vectors between the human modified environment and an urban forest in Rio de Janeiro. J Med Entomol. 2006:43:1112-20.

32. Diallo D, Chen R, Diagne CT, Ba Y, Dia I, Sall AA, et al. Bloodfeeding patterns of sylvatic arbovirus vectors in southeastern Senegal. Trans R Soc Trop Med Hyg. 2013;107:200-3.

33. Wei L, Kelly P, Zhang J, Yang Y, Zheng X, Tao J, et al. Use of a universal hydroxymethylbilane synthase (HMBS)-based PCR as an endogenous internal control and to enable typing of mammalian DNAs. Appl Microbiol Biotechnol. 2014;98:5579-87.

34. Lambert AJ, Lanciotti R. Laboratory diagnosis of arboviruses. In: Gubler DJ, Vasilakis N, editors. Arboviruses: molecular biology, evolution and control. Norfolk: Caister Academic Press; 2016. p. 271-7.

35. Shu PY, Huang JH. Current advances in dengue diagnosis. Clin Diagn Lab Immunol. 2004;11:642-50. 
36. Gubler DJ, Vasilakis N. Arboviruses: molecular biology, evolution and control. Norfolk: Caister Academic Press; 2016.

37. Muller DA, Depelsenaire AC, Young PR. Clinical and laboratory diagnosis of dengue virus infection. J Infect Dis. 2017;215(Suppl. 2):89-95.

38. Priyamvada L, Hudson W, Ahmed R, Wrammert J. Humoral cross-reactivity between Zika and dengue viruses: implications for protection and pathology. Emerg Microbes Infect. 2017;6:e33.

39. Kam YW, Pok KY, Eng KE, Tan LK, Kaur S, Lee WW, et al. Sero-prevalence and cross-reactivity of chikungunya virus specific anti-E2EP3 antibodies in arbovirus-infected patients. PLoS Negl Trop Dis. 2015;9:e3445.

40. Batista PM, Andreotti R, Chiang JO, Ferreira MS, Vasconcelos PF. Seroepidemiological monitoring in sentinel animals and vectors as part of arbovirus surveillance in the state of Mato Grosso do Sul, Brazil. Rev Soc Bras Med Trop. 2012;45:168-73.

41. Batista PM, Andreotti R, Almeida PS, Marques AC, Rodrigues SG, Chiang $\mathrm{JO}$, et al. Detection of arboviruses of public health interest in free-living New World primates (Sapajus spp.; Alouatta caraya) captured in Mato Grosso do Sul. Brazil. Rev Soc Bras Med Trop. 2013;46:684-90.

42. Kato F, Ishida Y, Kawagishi T, Kobayashi T, Hishiki T, Miura T, et al. Natural infection of cynomolgus monkeys with dengue virus occurs in epidemic cycles in the Philippines. J Gen Virol. 2013;94:2202-7.

43. Bernardo L, Izquierdo A, Prado I, Rosario D, Alvarez M, Santana E, et al. Primary and secondary infections of Macaca fascicularis monkeys with Asian and American genotypes of dengue virus 2. Clin Vaccine Immunol. 2008;15:439-46.

44. Digoutte JP, Calvo-Vilson MA, Mondo M, Traore-Lamizana M, Adam F. Continuous cell lines and immune ascitic fluid pods in arbovirus detection. Res Virol. 1992;143:417-22.

45. Monath TP, Kemp GE. Importance of non-human primates in yellow fever epidemiology in Nigeria. Trop Geogr Med. 1973;25:28-38.

46. National Centre for the Replacement Refinement and Reduction of Animals in Research. NC3Rs.The 3Rs. http://www.nc3rs.org.uk/the-3rs. Accessed 13 Sept 2018.

47. Braack L, Gouveia de Almeida AP, Cornel AJ, Swanepoel R, de Jager C. Mosquito-borne arboviruses of African origin: review of key viruses and vectors. Parasit Vectors. 2018;11:29.

48. Simmons JS, St. John JH, Reynolds FHK. Experimental studies of dengue. Phillipp J Sci. 1931;44:1-247.

49. Smith CE. The history of dengue in tropical Asia and its probable relationship to the mosquito Aedes aegypti. J Trop Med Hyg. 1956;59:243-51.

50. Hammon WMCD, Schrack WD Jr, Sather GE, Rudnick A. Serology of haemorrhagic fever patients in the Philippines (1956), in Bangkok (1958 1960 and in normal children and animals in Bangkok (1958). SEATO Med Res Monogr. 1961;2:45.

51. Rudnick A. Studies of the ecology of dengue in Malaysia: a preliminary report. J Med Entomol. 1965;2:203-8.

52. Rudnick A, Marchette NJ, Garcia R. Possible jungle dengue-recent studies and hypotheses. Jpn J Med Sci Biol. 1967;20(Suppl.):69-74.

53. Yuwono J, Suharyono W, Koiman I, Tsuchiya Y, Tagaya I. Seroepidemiological survey on dengue and Japanese encephalitis virus infections in Asian monkeys. Southeast Asian J Trop Med Public Health. 1984:15:194-200

54. Cardosa J, Ooi MH, Tio PH, Perera D, Holmes EC, Bibi K, et al. Dengue virus serotype 2 from a sylvatic lineage isolated from a patient with dengue hemorrhagic fever. PLoS Negl Trop Dis. 2009;3:e423.

55. Nakgoi K, Nitatpattana N, Wajjwalku W, Pongsopawijit P, Kaewchot S, Yoksan S, et al. Dengue, Japanese encephalitis and chikungunya virus antibody prevalence among captive monkey (Macaca nemestrina) colonies of northern Thailand. Am J Primatol. 2014;76:97-102.

56. Peiris JS, Dittus WPJ, Ratnayake CB. Seroepidemiology of dengue and other arboviruses in a natural population of toque macaques (Macaca sinica) at Polonnaruwa, Sri Lanka. J Med Primatol. 1993;22:240-5.

57. De Silva AM, Dittus WP, Amerasinghe PH, Amerashinge FP. Serologic evidence for an epizootic dengue virus infecting toque macaques (Macaca sinica) at Polonnaruwa, Sri Lanka. Am J Trop Med Hyg. 1999;60:300-6.

58. Wolfe ND, Kilbourn AM, Karesh WB, Rahman HA, Bosi EJ, Cropp BC, et al. Sylvatic transmission of arboviruses among Bornean orangutans. Am J Trop Med Hyg. 2001;64:310-6.
59. Inoue S, Morita K, Matias RR, Tuplano JV, Resuello RR, Candelario JR, et al. Distribution of three arbovirus antibodies among monkeys (Macaca fascicularis) in the Philippines. J Med Primatol. 2003;32:89-94.

60. Rodhain F. The role of monkeys in the biology of dengue and yellow fever. Comp Immunol Microbiol Infect Dis. 1991;14:9-19.

61. Saluzzo JF, Cornet M, Adam C, Eyraud M, Digoutte JP. Dengue 2 au Sénégal oriental: enquête sérologique dans les populations humaine et simienne, 1974-1975. Bull Soc Path Exp. 1986;79:313-22.

62. Traore-Lamizana M, Zeller H, Monlun E, Mondo M, Hervy JP, Adam F, et al. Dengue 2 outbreak in southeastern Senegal during 1990: virus isolations from mosquitoes (Diptera: Culicidae). J Med Entomol. 1994:31:623-7.

63. Fagbami AH, Monath TP, Fabiyi A. Dengue virus infections in Nigeria: a survey for antibodies in monkeys and humans. Trans R Soc Trop Med Hyg. 1977;71:60-5.

64. Rosen L. Observations on the epidemiology of dengue in Panama. Am J Hyg. 1958;68:45-58.

65. Hemme RR, Lopez-Ortiz R, Garcia BR, Sharp TM, Galloway RL, Elrod $M G$, et al. Serological evidence of infection with endemic human pathogens among free-ranging Old World monkeys in Puerto Rico. Am J Trop Med Hyg. 2016;94:1095-9.

66. Morales MA, Fabbri CM, Zunino GE, Kowalewski MM, Luppo VC, Enría DA, et al. Detection of the mosquito-borne flaviviruses, West Nile, dengue, Saint Louis encephalitis, Ilheus, Bussuquara, and yellow fever in free-ranging black howlers (Alouatta caraya) of northeastern Argentina. PLoS Negl Trop Dis. 2017;11:e0005351.

67. Catenacci LS, Ferreira M, Martins LC, De Vleeschouwer KM, Cassano $C R$, Oliveira LC, et al. Surveillance of arboviruses in primates and sloths in the Atlantic Forest, Bahia,Brazil. EcoHealth. 2018;15:777-91.

68. De Figueiredo ML, de Gomes CA, Amarilla AA, de Leandro SA, de Orrico SA, de Araujo RF, et al. Mosquitoes infected with denque viruses in Brazil. Virol J. 2010;7:152.

69. McIntosh BM. Antibody against chikungunya virus in wild primates in southern Africa. S Afr J Med Sci. 1970;35:65-74.

70. McCrae AW, Henderson BW, Kirya BG, Sempala SD. Chikungunya virus in the Entebbe area of Uganda: isolations and epidemiology. Trans $R$ Soc Trop Med Hyg. 1971;65:152-68.

71. Sow A, Faye O, Diallo M, Diallo D, Chen R, Faye O, et al. Chikungunya outbreak in Kedougou, southeastern Senegal in 2009-2010. Open Forum Infect Dis. 2017:5:ofx259.

72. Vourc'h G, Halos L, Desvars A, Boué F, Pascal M, Lecollinet S, et al. Chikungunya antibodies detected in non-human primates and rats in three Indian Ocean islands after the 2006 CHIKV outbreak. Vet Res. 2014;45:52.

73. Halstead SB, Udomsakdi S. Vertebrate hosts of chikungunya virus. Bull World Health Organ. 1966;35:89.

74. Marchette NJ, Rudnick A, Garcia R, MacVean DW. Alphaviruses in peninsular Malaysia: I. Virus isolations and animal serology. Southeast Asian J Trop Med Public Health. 1978;9:317-29.

75. Apandi Y, Nazni WA, Noor Azleen ZA, Vythilingham I, Noorazian MY, Azahari AH, et al. The first isolation of chikungunya virus from nonhuman primates in Malaysia. J Gen Mol Virol. 2009;1:35-9.

76. Sam IC, Chua CL, Rovie-Ryan JJ, Fu JY, Tong C, Sitam FT, et al. Chikungunya virus in macaques, Malaysia. Emerg Infect Dis. 2015;21:1683-5.

77. Moreira-Soto A, Carneiro IO, Fischer C, Feldmann M, Kümmerer BM, Silva NS, et al. Limited evidence for infection of urban and peri-urban nonhuman primates with Zika and chikungunya viruses in Brazil. mSphere. 2018;3:e00523-17.

78. Higgs $S$, Vanlandingham D. Chikungunya virus and its mosquito vectors. Vector Borne Zoonotic Dis. 2015;2015(15):231-40.

79. Lourenço-de-Oliveira R, Failloux AB. High risk for chikungunya virus to initiate an enzootic sylvatic cycle in the tropical Americas. PLoS Negl Trop Dis. 2017;11:e000569.

80. Tsetsarkin KA, Chen R, Weaver SC. Interspecies transmission and chikungunya virus emergence. Curr Opin Virol. 2016;16:143-50.

81. McCrae AW, Kirya BG. Yellow fever and Zika virus epizootics and enzootics in Uganda. Trans R Soc Trop Med Hyg. 1982;76:552-62.

82. Vasilakis N, Weaver SC. Flavivirus transmission focusing on Zika. Curr Opin Virol. 2017:22:30-5 
83. Diallo D, Sall AA, Diagne CT, Faye $O$, Faye $O$, Ba Y, et al. Zika virus emergence in mosquitoes in southeastern Senegal, 2011. PLoS ONE. 2014;9:e109442.

84. Buechler CR, Bailey AL, Weiler AM, Barry GL, Breitbach ME, Stewart LM, et al. Seroprevalence of Zika virus in wild African green monkeys and baboons. mSphere. 2017;2:e00392-16.

85. Bueno MG, Martinez N, Abdalla L, Duarte Dos Santos CN, Chame M. Animals in the Zika virus life cycle: what to expect from megadiverse Latin American countries. PLoS Negl Trop Dis. 2016;10:e0005073.

86. Vorou R. Zika virus, vectors, reservoirs, amplifying hosts, and their potential to spread worldwide: what we know and what we should investigate urgently. Int J Infect Dis. 2016;48:85-90.

87. Mishra B, Behera B. The mysterious Zika virus: adding to the tropical flavivirus mayhem. J Postgrad Med. 2016;62:249-54.

88. Epelboin Y, Talaga S, Epelboin L, Dusfour I. Zika virus: an updated review of competent or naturally infected mosquitoes. PLoS Negl Trop Dis. 2017;11:e0005933.

89. Pettersson JH, Bohlin J, Dupont-Rouzeyrol M, Brynildsrud OB, Alfsnes K, Cao-Lormeau VM, et al. Re-visiting the evolution, dispersal and epidemiology of Zika virus in Asia. Emerg Microbes Infect. 2018:7:79.

90. Marchette NJ, Garcia R, Rudnick A. Isolation of Zika virus from Aedes aegypti mosquitoes in Malaysia. Am J Trop Med Hyg. 1969;8:411-5.

91. Kilbourn AM, Karesh WB, Wolfe ND, Bosi EJ, Cook RA, Andau M. Health evaluation of free-ranging and semi-captive orangutans (Pongo pygmaeus pygmaeus) in Sabah, Malaysia. J Wildl Dis. 2003;39:73-83.

92. Favoretto S, Araujo D, Oliveira D, Duarte N, Mesquita F, Zanotto P, et al. First detection of Zika virus in neotropical primates in Brazil: a possible new reservoir. bioRxiv. 2016. https://doi.org/10.1101/049395.

93. Terzian ACB, Zini N, Sacchetto L, Rocha RF, Parra MCP, Del Sarto JL, et al. Evidence of natural Zika virus infection in neotropical non-human primates in Brazil. Sci Rep. 2018;8:16034.

94. Gould E, Pettersson J, Higgs S, Charrel R, de Lamballerie X. Emerging arboviruses: why today? One Health. 2017;4:1-13.
95. Esposito DLA, Fonseca BALD. Will Mayaro virus be responsible for the next outbreak of an arthropod-borne virus in Brazil? Braz J Infect Dis. 2017; 21:540-4

96. de Thoisy B, Gardon J, Salas RA, Morvan J, Kazanji M. Mayaro virus in wild mammals, French Guiana. Emerg Infect Dis. 2003;9:1326-9.

97. Seymour C, Peralta PH, Montgomery GG. Serologic evidence of natural togavirus infections in Panamanian sloths and other vertebrates. Am J Trop Med Hyg. 1983;32:854-61.

98. Talarmin A, Chandler LJ, Kazanji M, de Thoisy B, Debon P, Lelarge J، et al. Mayaro virus fever in French Guiana: isolation, identification, and seroprevalence. Am J Trop Med Hyg. 1998;59:452-6.

99. Paulo M, Renato A, Da Carneiro Rocha T, Eliane C, Navarro da Silva $\mathrm{M}$, Walfridge, et al. Serosurvey of arbovirus in free-living non-human primates (Sapajus spp.) in Brazil. J Environ Anal Chem. 2015;2:155.

100. Sakkas H, Bozidis P, Franks A, Papadopoulou C. Oropouche fever: a review. Viruses. 2018;10:175.

101. Nunes MR, Martins LC, Rodrigues SG, Chiang JO, Azevedo Rdo S, da Rosa AP, et al. Oropouche virus isolation, southeast Brazil. Emerg Infect Dis. 2005;11:1610-3.

102. Rezza G, Chen R, Weaver SC. O'nyong-nyong fever: a neglected mosquito-borne viral disease. Pathog Glob Health. 2017;111:271-5.

103. White S, Lednicky J, Okech BA, Morris JG Jr, Dunford JC. Spondweni virus in field-caught Culex quinquefasciatus mosquitoes, Haiti, 2016. Emerg Infect Dis. 2018;24:1765-7.

104. Kokernot RH, Mcintosh BM, Worth CB, De Moraist, Weinbren MP. Isolation of viruses from mosquitoes collected at Lumbo, Mozambique. I. Lumbo virus, a new virus isolated from Aedes (Skusea) pembaensis Theobald. Am J Trop Med Hyg. 1962;11:678-82.

\section{Publisher's Note}

Springer Nature remains neutral with regard to jurisdictional claims in published maps and institutional affiliations.
Ready to submit your research? Choose BMC and benefit from:

- fast, convenient online submission

- thorough peer review by experienced researchers in your field

- rapid publication on acceptance

- support for research data, including large and complex data types

- gold Open Access which fosters wider collaboration and increased citations

- maximum visibility for your research: over $100 \mathrm{M}$ website views per year

At BMC, research is always in progress.

Learn more biomedcentral.com/submissions 